\title{
Last-glacial to postglacial climate formation in the continental interior inferred from multi-proxy records of Lake Hovsgol, Mongolia
}

Last-glacial to postglacial climate formation

K. Minoura et al.

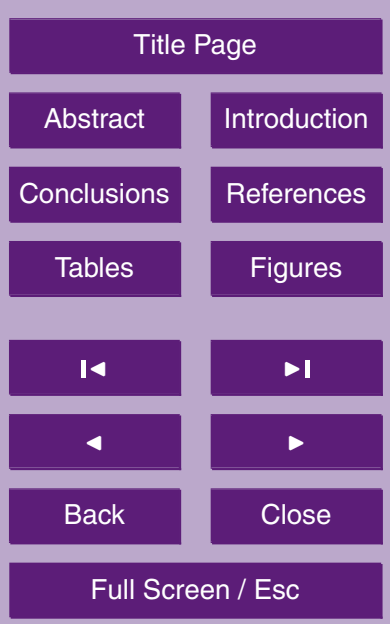

Printer-friendly Version

Interactive Discussion 


\section{Abstract}

Knowledge of the evolution of arboreal forests is necessary to interpret the cause of climate formation in intracontinental regions. Paleoproxy records of sediment cores from Lake Hovsgol, Mongolia show that watershed conditions have fluctuated widely during 5 the last $30 \mathrm{ka}$ because of changing orbital parameters. Termination of glacial cooling and the subsequent prevalence of deglacial warming were consequences of solar forcing. Arboreal forests exerted an important influence on the atmospheric moisture cycle at high latitudes. Air pressure decreased because of raised humidity from water vapor penetration into inland regions that occurred along with summer monsoons. Data 10 showing utilization of solar energy are necessary for establishing climate conditions. Atmospheric warming under increased insolation caused a shift of the monsoon limit to the north, amplifying the summer moisture supply to the watershed. That amplification engendered the appearance of the maximum vegetation in the Hovsgol drainage basin at the beginning of the Holocene. The retreat of arboreal forests that occurred along with decreased solar energy shrank the humidification-vegetation feedback loop, thereby decreasing the atmospheric humidity. The consequently lowered vapor pressure contributed to the incursion of cool air masses from the north.

\section{Introduction}

Southwest of Lake Baikal in Mongolia lies Lake Hovsgol, the second largest and second deepest lake in the Baikal watershed. The lake's north-south axis is $136 \mathrm{~km}$, varying between 15 and $35 \mathrm{~km}$ from east to west. The maximum water depth is $262 \mathrm{~m}$ (Kozhova et al., 1989). However, the temporal sequence of terrace deposits shows fluctuation of the lake level on a tens-of-meter scale in response to Late Quaternary climate changes (Krivonogov, 2006). The Hovsgol Basin, which formed under a strikeslip tectonic regime in the Baikal Rift System (San'kov et al., 2003), is separated from the Baikal depression by east-west-trending mountain ranges (Fig. 1). Fedotov et
6, 385-420, 2010

\section{Last-glacial to postglacial climate formation}

K. Minoura et al.

\section{Title Page}

Abstract

Introduction

Conclusions

Tables

References

Figures

14

$\Delta$

4

Back

$\checkmark$

Close

\section{Full Screen / Esc}

Printer-friendly Version

Interactive Discussion

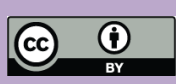


al. (2004) proposed that the rift system became activated and a mantle plume intrusion occurred between ca. 9.5 Ma and 0.4 Ma. Since then, the rifting has slowed, and fine-grained terrigenous materials have gradually filled the basin.

The water surface of Lake Hovsgol is at 1667 ma.s.I. (Kozhova et al., 1989); high 5 dividing ridges surround the narrow catchment of the northern part of the basin. The modern climatic conditions, cold, dry winters and mildly wet summers specialize the water circulation in this high-altitude watershed (Namkhaijantsan, 2006). The runoff originates in mountainous regions of the basin, and water is apparently supplied to the lake mostly by precipitation, which, totaling as much as $350 \mathrm{~mm}$ annually, occurs 10 mostly as rain in summer (Batsyk et al., 1976). Evaporation is a major cause of water loss in the basin; nearly $90 \%$ of rainfall is lost to evaporation (Namkhaijantsan, 2006). The Siberian High dominates the climate in winter: cold dry air masses cover the basin and the air temperature decreases to as low as $-50^{\circ} \mathrm{C}$ (Kozhova et al., 1989). The extreme climate has greatly influenced the lake evolution. Paleoclimate proxy records 15 from the lake are expected to reflect stadial-interstadial changes in the atmospheric moisture supply directly to the continental interior. Such knowledge is useful to interpret the feedback effect of terrestrial processes on the continental climate. Considering the active hydrologic budget in the watershed, it is reasonable to interpret that the lake level changed greatly during the last glacial-interglacial transition. Prokopenko et al. (2005) estimated that a lake-level rise extending to $100 \mathrm{~m}$ took place at around $15.4 \mathrm{cal} \mathrm{ka} \mathrm{BP}$.

Large fluctuations of air mass movements have occurred in Central Asia throughout the Late Quaternary (Herzschuh, 2006), and changes in atmospheric humidity are crucial for elucidation of mechanisms triggering climatic cooling or warming. Herein, we present last-glacial to postglacial records of paleoclimate proxies from Lake Hov-

sgol. The summer monsoon developed because increased solar-energy absorption of the ocean surface transported moisture from oceans onto continents, thereby producing warm, wet climatic conditions in the Asian interior as orbital-scale insolation gradually increased (e.g. Dykoski et al., 2005). Associating this response with highaltitude terrestrial processes via changing atmospheric desiccation-precipitation re-
$6,385-420,2010$

\section{Last-glacial to postglacial climate formation}

K. Minoura et al.

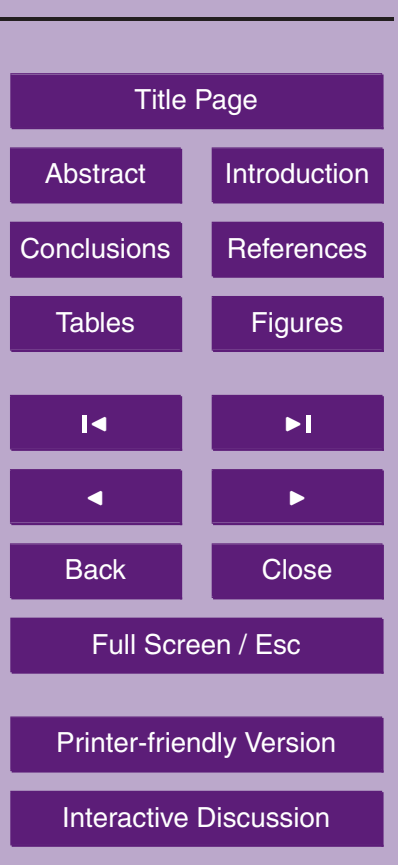


actions, we suggest that the enhanced solar radiation activity accelerated deglacial warming through feedback from increasing vegetation.

\section{East asian meteorological features}

The Siberian High affects atmospheric circulation in regions at middle latitudes of East5 ern Asia; prevailing winds bring cool dry air masses that strongly influence regional climate formation (Herzschuh, 2006). The climatic data of air temperature and precipitation (Kozhova et al., 1989) and the oxygen isotope values of lake water (refer to Sect. 4.4.3, Lake water isotopes) indicate that summertime precipitation is the main source of water to the continental interior.

10 Figure 1 portrays the distribution of oxygen isotope ratios $\left(\delta^{18} \mathrm{O} ; \%\right.$ \% SMOW, Standard Mean Ocean Water) in summer (June-September) and winter (November-March) precipitation in Eastern Asia. The ratios are averaged values of long-term (1960-2001) International Atomic Energy Agency (IAEA) data. The averaged oxygen isotope $\left(\delta^{18} \mathrm{O}\right)$ values of precipitation in Siberia are $-10 \%$ in summer and $-25 \%$ in winter. A large 15 amplitude of fluctuation, ca. $15 \%$ o, is also suggested by the $\delta^{18} \mathrm{O}$ range (ca. $5 \%$ o) of modern equid teeth (Fowell and Peck, 1997). Because of the location of continental interior, the watershed receives isotopically light precipitation from cool air masses in winter. The small isotope fractionation in summertime precipitation reflects the major influence of the SE Asian monsoon in the extensive area of Eastern Asia when solar 20 radiation is increased. Wintertime precipitation is slight, and the lake water oxygen isotopes are a signal of net effective precipitation from warm air masses.

The circulation of humid air masses during the Siberian summer is controlled considerably by the SE Asian monsoon and partly by the prevailing westerly winds (Herzschuh, 2006); the atmospheric moisture supply to the northern region beyond 25
6, 385-420, 2010

\section{Last-glacial to postglacial climate formation}

K. Minoura et al.

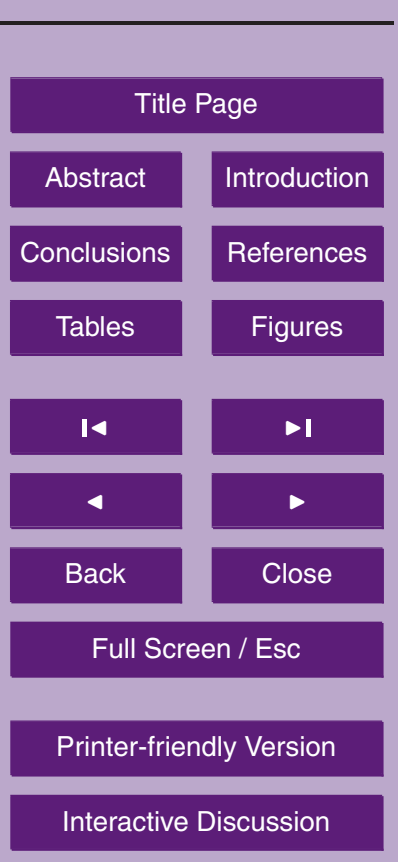




\section{Materials}

We studied three short cores (X103, X106, X107) drilled in the central area of Lake Hovsgol with no sediment loss or mixing (Fig. 2; X103, $50^{\circ} 53^{\prime} 180^{\prime \prime} \mathrm{N}, 100^{\circ} 27^{\prime} 837^{\prime \prime} \mathrm{E}$; $\left.X 106,50^{\circ} 53^{\prime} 018^{\prime \prime} \mathrm{N}, 100^{\circ} 21^{\prime} 371^{\prime \prime} \mathrm{E} ; \mathrm{X} 107,51^{\circ} 11^{\prime} 526^{\prime \prime} \mathrm{N}, 100^{\circ} 24^{\prime} 990^{\prime \prime} \mathrm{E}\right)$. The Hov-

5 sgol Basin is divided into north and south areas by a well at around $51^{\circ} \mathrm{N}$. Cores X103 and X106 were recovered from the south basin, and core X107 from the north basin. Each core consisted of two major lithological units separated by a transitional unit. The lower unit was composed of dark, olive-gray laminated silty clay; the upper unit consisted of olive-gray diatomaceous mud (Fig. 2). The transitional unit comprised massive, dark gray, marly clay, and displayed weak sediment disturbance by infaunal burrowing. Calcareous horizons in the lower unit yielded well-preserved fossil ostracod shells belonging to three major genera: Candona, Cytherissa, and Limnocythere. Ostracod fossils did not occur in diatomaceous horizons. Underwater bacterial degradation of accumulated organic remnants of algal blooms released interstitial carbonate 5 and bicarbonate ions, which dissolved shell calcite in the initial stage of sediment burial. In Lake Baikal, diatomaceous layers are characteristics for interglacial and interstadial intervals (Prokopenko et al., 2006), although sediment layers without frustules and organic remains were formed under cold-climate conditions (Sakai et al., 2005). Strata with ostracods are therefore distinctive for a depositional environment of lowered productivity resulting from the reduction in nutrient input. We subsampled sediments from cores at intervals of about $1.5 \mathrm{~cm}$ for analyses of sediment grain-size composition, clay mineralogy, biogenic silica concentration, and pollen and diatom paleontology.
6, 385-420, 2010

\section{Last-glacial to postglacial climate formation}

K. Minoura et al.

\section{Title Page}

Abstract

Introduction

Conclusions

References

Tables

Figures
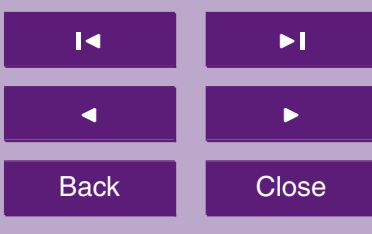

Back

Close

Printer-friendly Version

Interactive Discussion 


\section{Methods and results}

\subsection{Grain size}

About $40 \mathrm{mg}$ of wet sediments were dispersed in a liter of de-ionized water. Then we analyzed the solution suspending sediment grains using an automatic grain-size ana-

5 lyzer with a laser diffraction system (SALD $3000 \mathrm{~J}$; Shimadzu Corp., Japan). The analytical data were expressed as volume-percent distributions with 51 logarithmic scales of grain size ranging from $0.1 \mu \mathrm{m}$ to $2000 \mu \mathrm{m}$. The volumes of clay (finer than $2 \mu \mathrm{m}$ ), silt $(2-62 \mu \mathrm{m})$, and sand (coarser than $62 \mu \mathrm{m})$ fractions were calculated as the sums of grains. The calibrated results for clay $(0.33-2.00 \mu \mathrm{m})$ concentration are given in 10 Table 1.

Fine silt and clay are the major components of the X103 sediments. From the concentration of clay-sized grains, core X103 was separated into three stratigraphic sections: the lower (deeper than 61.25), middle (61.25-13.75 cm), and upper (shallower than $13.75 \mathrm{~cm}$ ). In the lower section, the quantity of clay was generally high: $16.82 \%$ on average. The middle section showed an upward decreasing trend in the clay concentration. The upper section was characterized by a high silt content of $97-98 \%$ on average, and very low sand and clay contents. The silt fraction consisted of frustules and their fragments, which clearly designated the lithological difference of this section (upper unit) from the middle section (transitional unit). The major components of core X106 were fine silt and clay. Considering the quantity of clay-sized fractions, the core was separable into three sections: the lower (deeper than 79.75), middle (79.75$45.75 \mathrm{~cm}$ ), and upper (shallower than $45.75 \mathrm{~cm}$ ). The clay content of the lower section was higher than $15 \%$, with an average value of $20.12 \%$. The middle section exhibited an upward decrease in clay concentration. The upper section displayed an extremely
6, 385-420, 2010

\section{Last-glacial to postglacial climate formation}

K. Minoura et al.

\section{Title Page}

Abstract

Introduction

Conclusions

References

Tables

Figures

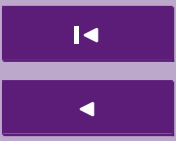

$\Delta \mathbf{I}$

Back

\section{Close}

\section{Full Screen / Esc}

Printer-friendly Version

Interactive Discussion jor grain component of the upper section, was made up of siliceous shells and shell fragments of diatoms, showing that the base of the upper section corresponded with the top of the transitional unit. Core X107 was composed mostly of clay and fine silt.

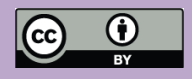


The core components were classified into three sections based on the clay concentration: the lower (deeper than 76.75), middle $(76.75-53.50 \mathrm{~cm}$ ), and upper (shallower than $53.50 \mathrm{~cm}$ ). The lower section was rich in clay-sized particles; clay fractions were higher than $20 \%$, accompanied by large fluctuations exceeding $6 \%$ at some horizons.

5 The middle section exhibited an upward decreasing trend of clay concentration. The upper section was distinctive for high silt content of $99.5 \%$ on average, and the silt fraction was composed of frustules and their fragments. The dominance of skeletal frameworks as sediment grains of the upper section presented a marked contrast to the middle section, displaying that the top of the middle section corresponded with the 10 top of the transitional unit.

\subsection{Mineralogy}

Clay-sized grains finer than $2 \mu \mathrm{m}$ were separated in a water column by allowing coarse sediments to settle. About $2 \mathrm{ml}$ of clay solution was dropped onto a glass slide; oriented clay samples were made with drying at room temperature. The slide samples 15 were examined using X-ray diffraction with a diffractometer (CuK $\alpha$ radiation, $40 \mathrm{kV}$, $45 \mathrm{~mA}$, PW 1821; Philips Co., Netherlands). We measured the full width at half maximum (FWHM) of the 10- $\AA$ illite peaks on the resulting diffractograms between $2^{\circ}$ and $18^{\circ}$ with a step size of $0.02^{\circ}$. We also examined changes in the diffractograms after Mg-saturation and $\mathrm{K}$-saturation of clays, ethylene glycol-solvation of Mg-saturated 20 samples, and one-hour-heating of K-saturated samples to 300 and $550^{\circ} \mathrm{C}$ to check the clay minerals in detail (Moore and Reynolds, 1997).

The FWHM of a $10-\AA$ peak from the X-cores is presented in Table 1. In the case of core $\mathrm{X} 103$, the peak width was mostly constant through the section with the average of 0.34 . In the stratigraphic interval deeper than $97.75 \mathrm{~cm}$ of core $\mathrm{X} 106$, the peak width 25 exhibited upward widening from 0.31 to 0.45 . In the upper part of the core shallower than $97.75 \mathrm{~cm}$ depth, the peak width showed a gradual decrease upward from 0.45 to 0.13 with small fluctuations. In the stratigraphic section deeper than $104.25 \mathrm{~cm}$ of core $\mathrm{X} 107$, the peak width fluctuated between 0.35 and 0.42 . The upper $104.25 \mathrm{~cm}$ part of

$6,385-420,2010$

\section{Last-glacial to postglacial climate formation}

K. Minoura et al.

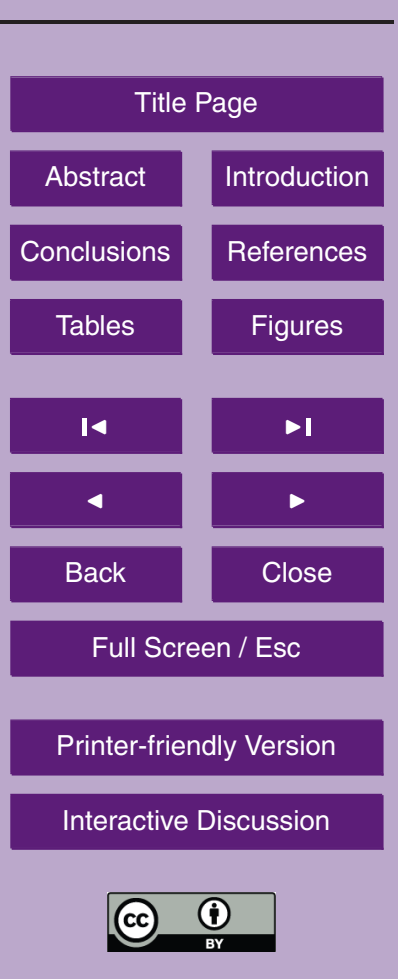


the core exhibited an upward decrease in the peak width from 0.43 (bottom) to 0.24 (top). These mineralogical tests included a common result of upward decreasing illite peak-width through the diatomaceous mud, implying enhancement of chemical and biochemical weathering of the crustal surface during increased surface productivity.

\section{4.3 Paleontology}

\subsubsection{Fossil pollen}

Terrestrial vegetation is an important proxy reflecting continental climate fluctuations. To clarify the response of flora for changing climatic elements, we investigated the concentrations and compositions of fossil pollen grains in the sediment samples of core $10 \mathrm{X}$ 107. Approximately $1 \mathrm{~cm}^{3}$ wet subsamples were analyzed using the standard $\mathrm{KOH}-$ $\mathrm{HF}$-acetolysis procedure and heavy-liquid $\left(\mathrm{ZnCl}_{2}\right.$ solution with a specific gravity of 1.68) separation method (Faegri et al., 1989) after addition of $1 \mathrm{ml}$ of marker liquid containing 40000 grains of plastic microspheres ( $25 \mu \mathrm{m}$ diameter) (Gordon, 1986). The pollen grains were counted on a glass slide under an optical microscope at $\times 400$ magnifi15 cation after chemical processing. The pollen concentration was calculated using the following equation.

$N c=N p p \cdot C m / N m / V$

Therein, $N c$ is the pollen concentration (grains $/ \mathrm{cm}^{3}$ ), and $N p p$ is the number of pollen grains counted. In addition, $\mathrm{Cm}$ is the marker concentration (40000 grains $/ \mathrm{cm}^{3}$ ), and ${ }_{20} \mathrm{Nm}$ is the number of markers counted; $V$ is the sediment volume $\left(\mathrm{cm}^{3}\right)$. The total amount of pollen was 5000 grains $/ \mathrm{cm}^{3}$ or less. Therefore, we measured fossil pollen in the visual field until the counts of microspheres reached 200 grains. All pollen grains in $5 \mathrm{~mm}^{3}$ of sediment were counted in this case. When the total amount of pollen in the sediment exceeded 5000 grains $/ \mathrm{cm}^{3}, 200$ grains of pollen fossils in the visual field, where at least 40 grains of microspheres were included, were counted. In such a case, it follows that the fossil pollens in sediment samples of $1-5 \mathrm{~mm}^{3}$ were counted.

$6,385-420,2010$

\section{Last-glacial to postglacial climate formation}

K. Minoura et al.

\section{Title Page}

Abstract Introduction

Conclusions References

Tables Figures
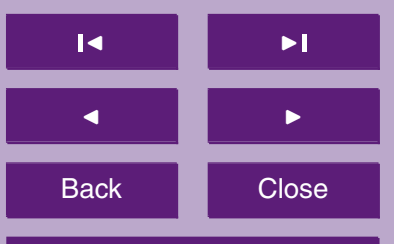

Back

Close

Full Screen / Esc

Printer-friendly Version

Interactive Discussion

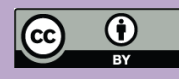


Throughout the lower unit, the pollen concentration was less than $6500 \mathrm{grains} / \mathrm{cm}^{3}$, with an average of 4320 grains $/ \mathrm{cm}^{3}$. The pollen grains occurred slightly from the transitional unit, and reached the maximum at around the base of the upper unit (903750 grains $/ \mathrm{cm}^{3}$ ). Above this level, the palynological data showed tapering concentration.

Pinus and Larix were the major coniferous pollens, with occasional Picea. The major broad-leaved trees and shrubs were Betula, Corylus, Alnus, and Salix; Ephedra were rare. The herbaceous pollens consisted mainly of Gramineae, Artemisia, Chenopodiaceae, and Alisma. The Pinus concentration was very low in the lower unit $\left(<2500\right.$ grains $\left./ \mathrm{cm}^{3}\right)$. Immediately above the base of the upper unit, however, Pinus 10 showed its peak concentration of 225940 grains $/ \mathrm{cm}^{3}$; then decreased upward. The stratigraphic fluctuation of Pinus pollens correlated with that of the total pollen concentration, suggesting that Pinus was representative of the flora in the watershed. The $B e-$ tula concentration was very low $\left(<2000 \mathrm{grains} / \mathrm{cm}^{3}\right)$ in the middle horizon of the transitional unit, above which Betula pollen started to increase. After reaching the maximum 15 (about 350000 grains $/ \mathrm{cm}^{3}$ ) at $46.25 \mathrm{~cm}$ depth, Betula decreased rapidly upward to 6930 grains $/ \mathrm{cm}^{3}$. The pollen concentration of Alnus was quite low $\left(<1000 \mathrm{grains} / \mathrm{cm}^{3}\right)$ through the transitional unit of the core. Alnus started to increase in concentration through the middle half of the transitional unit, and reached the maximum $(<12000$ grains $/ \mathrm{cm}^{3}$ ) at the lower horizon of the upper unit (50-30 cm depth), then exhibited a decreasing trend upward. Salix began to appear at the lower part of the transitional unit (ca. $70 \mathrm{~cm}$ depth), and reached the peak concentration (3830 grains $/ \mathrm{cm}^{3}$ ) just above the base of the upper unit $(46.25 \mathrm{~cm}$ depth). It decreased abruptly upward with two disappearances at 41.25 and $18.75 \mathrm{~cm}$ depths. Fossil pollen Artemisia occurred throughout the core section of $\mathrm{X} 107$; however, the pollen concentration was very low 25 (less than 1000 grains $/ \mathrm{cm}^{3}$ ) in the lower unit (less than $80 \mathrm{~cm}$ depth). In the transitional unit, the concentration slightly increased upward as much as $5000 \mathrm{grains} / \mathrm{cm}^{3}$, and reached the highest value of 38290 grains $/ \mathrm{cm}^{3}$ at the base of the upper unit $(46.25 \mathrm{~cm}$ depth). Above the maximum, Artemisia decreased in concentration upward.
$6,385-420,2010$

\section{Last-glacial to postglacial climate formation}

K. Minoura et al.

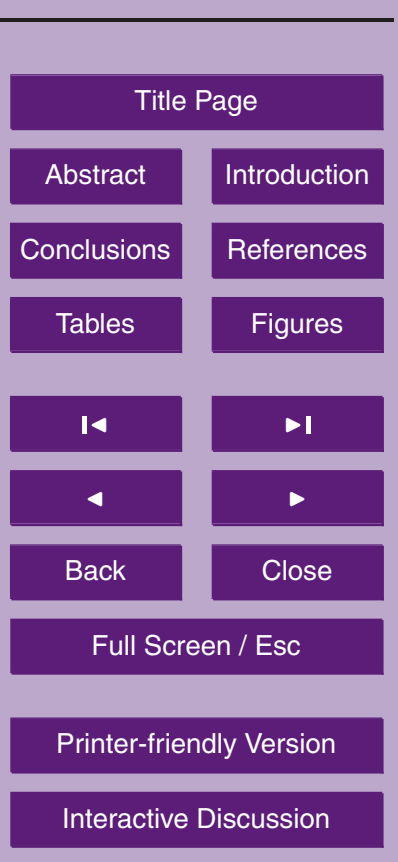




\subsubsection{Fossil diatoms}

Photosynthetic organisms in aquatic environments are dependent on insolation and the nutrient influx. Planktonic diatoms are the most representative autotrophs in aquatic environments (Prokopenko et al., 2007); their remains are preserved in sediment 5 records as fossil frustules (Khursevich and Prokopenko, 2009).

To prepare the glass slides for the observation of fossil diatoms, a ca. $0.1 \mathrm{~cm}^{3}(10-$ $15 \mathrm{mg}$ ) wet sediment sample was dried at $60^{\circ} \mathrm{C}$ for $24 \mathrm{~h}$; then $6 \mathrm{ml}$ of ion-exchanged water was added to the dry sample. The mixture was shaken until all sediments were in suspension. Quantitative drops of the suspension were spilled onto an $18 \mathrm{~mm} \cdot 18 \mathrm{~mm}$ cover glass and stirred to spread the suspension evenly over a cover glass; then the cover glass was dried on a hot plate at moderate temperature. After the suspension dried, the cover glass was fixed with mount media. Diatom valves were measured under an optical microscope at $1000 \times$ magnification. Samples were rich in frustules: more than 200 valves were analyzed on each slide. When diatoms were scarce on the 15 sample slides, measurement was continued until $9.0 \mathrm{~mm}^{2}$ of the slide area (5 lines on the cover glass) was scanned. Diatom concentration (valves/g) was calculated using the following equation.

$N g=N v p \cdot(1 / D) \cdot(S c / S)$

In that equation, $N g$ is the number of valves (valves/g), $N v p$ is the number of valves 20 identified, $D$ is the dry weight $(\mathrm{g})$ of the sample dropped on the cover glass, $S$ is the scanning area $\left(\mathrm{mm}^{2}\right)$, and $S c$ is the area of the cover glass $(18 \mathrm{~mm} \cdot 18 \mathrm{~mm})$.

The frustule occurrence showed that the fossil diatom assemblages consisted mainly of three Centrales genera (Cyclotella, Stephanodiscus, and Aulacoseira) and some Pennales species. Genus Cyclotella was classified into six species (C. ocellata, C. sibirica, C. bodanica, C. minuta, C. sp. A, and C. sp. B), and genus Stephanodiscus four species ( $S$. jamsranii, $S$. mongolicus, $S$. sp. A, and $S$. sp. B). Genus Aulacoseira included a single species $(A$. sp.).
6, 385-420, 2010

\section{Last-glacial to postglacial climate formation}

K. Minoura et al.

\section{Title Page}

Abstract Introduction

Conclusions References

Tables Figures
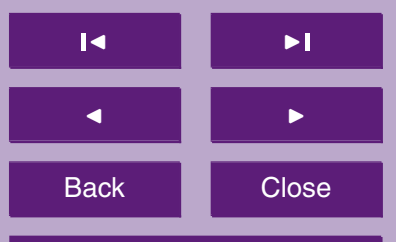

Back

Close

Full Screen / Esc

Printer-friendly Version

Interactive Discussion

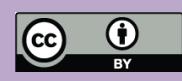


Diatom fossils did not occur from the lower unit. More than $90 \%$ of the fossil diatoms from the X-cores were $C$. ocellata, which began to appear at the unit boundary between the lower and the transition of cores X106 and X107. The total diatom abundance increased upward through the transitional unit, and reached the maximum

$5\left(1.7 \times 10^{8}\right.$ valves $\left./ g\right)$ in the middle of the upper unit. Above this, the frustule concentration was reduced by half, and fluctuated widely between $1.3 \times 10^{8}$ and $10 \times 10^{8}$ valves $/ \mathrm{g}$. C. bodanica did not occur from the uppermost part of the cores. Core X103 was characteristic for insignificant frustule occurrence.

\subsection{Geochemistry}

\subsubsection{Biogenic silica}

We measured biogenic silica concentrations in sediment samples using a rapid wetalkaline extraction method that was slightly modified from the procedure of Mortlock and Froelich (1989) to enable determination of accurate values despite small sample volumes.

15 Each of the ca. $0.5 \mathrm{~cm}^{3}$ wet sediment samples was dried at $20^{\circ} \mathrm{C}$. After treating the homogenized sample with $0.5 \mathrm{~N} \mathrm{HCl}$ for $24 \mathrm{~h}$ to remove carbonates, the solution was centrifuged and decanted. The residual products collected using a filter paper were washed several times with ion-exchanged water; then dried at $60^{\circ} \mathrm{C}$. The dried residues were used for quantitative analyses of biogenic silica. Biogenic silica (BioSi) 20 was analyzed using inductively coupled plasma atomic emission spectrometry (ICPAES; ICAP 61E Trace, Thermo Jarrell Ash, USA). The silica concentration was calculated from the silica and aluminum levels in the sample solution as shown below.

BioSi $($ weight $\%)=2.4 \cdot(\mathrm{Si}-1.77 \cdot \mathrm{Al})$

In that equation, $\mathrm{Si}$ is the amorphous silica concentration (weight \%), and $\mathrm{Al}$ is the 25 aluminum concentration (weight \%) in the solution (contamination with clay-derived
$6,385-420,2010$

\section{Last-glacial to postglacial climate formation}

K. Minoura et al.

\section{Title Page}

Abstract Introduction

Conclusions References

Tables Figures
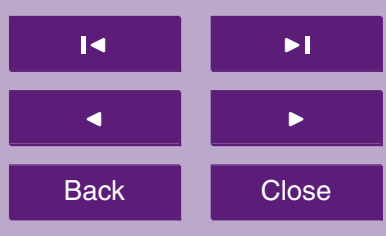

Back

Close

Full Screen / Esc

Printer-friendly Version

Interactive Discussion

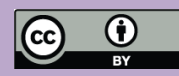


silica was corrected for by ICP-AES measurement data of aluminum). The results of the biogenic silica analysis of X-cores are presented in Table 1.

In the lower unit, the biogenic silica content was very low, with an average value of about 2.5 weight \% or less, which was the limit of detection. Biogenic silica gradually 5 increased upward throughout the lower unit and the lower part of the transitional unit, and reached the highest value at the basal part of the upper unit (15.30 weight \% at the $32.25 \mathrm{~cm}$ depth of Core X106; 12.61 weight \% at the $46.25 \mathrm{~cm}$ depth of Core $\mathrm{X} 107)$. The silica abruptly decreased above the horizon of maximum concentration and maintained an average level of ca. 8.5 weight \% afterwards, with slight fluctuations.

\subsubsection{Ostracod shell calcite isotopes}

To estimate aquatic productivity and the evaporation and precipitation of the lake, we measured stable oxygen and carbon isotope anomalies $\left(\delta^{18} \mathrm{O}\right.$ and $\left.\delta^{13} \mathrm{C}\right)$ of the ostracods' calcite shells. Well-preserved ostracod carapaces without adhesive materials were analyzed using an automated carbonate device (Kiel III; Finnigan MAT, USA) attached to a mass spectrometer (Delta S; Finnigan MAT, USA). Candona, Cytherissa, and Limnocythere were the common ostracod genera in Lake Hovsgol (Poberezhnaya et al., 2006); Cytherissa lacustris occurred successively from the calcareous horizons of the lower unit. Therefore, we selected calcite shells of Cytherissa lacustris as the object of study.

20 The sediments adopted for isotope analysis were sampled at intervals of $1.5 \mathrm{~cm}$ from cores X103 and X106, and at intervals of $2.5 \mathrm{~cm}$ from X107. After macerating sediments in distilled water at room temperature, the slime was wet-sieved through a 250 -mesh screen (63 $\mu \mathrm{m}$ opening) and then air-dried. At least $0.2 \mathrm{mg}$ of fossil homogeneous ostracod carapaces without accretion was subsampled from dried residues under a stereomicroscope. A subsample of about $0.2 \mathrm{mg}$ was reacted with phosphoric acid at a constant temperature of $70^{\circ} \mathrm{C}$ in an individual reaction vessel. Isotopic ratios were corrected for ${ }^{17} \mathrm{O}$ interferences using equations presented by Santrock et al. (1985). Results are reported in the conventional $\delta$ notation relative to the Vienna

6, 385-420, 2010

\section{Last-glacial to postglacial climate formation}

K. Minoura et al.

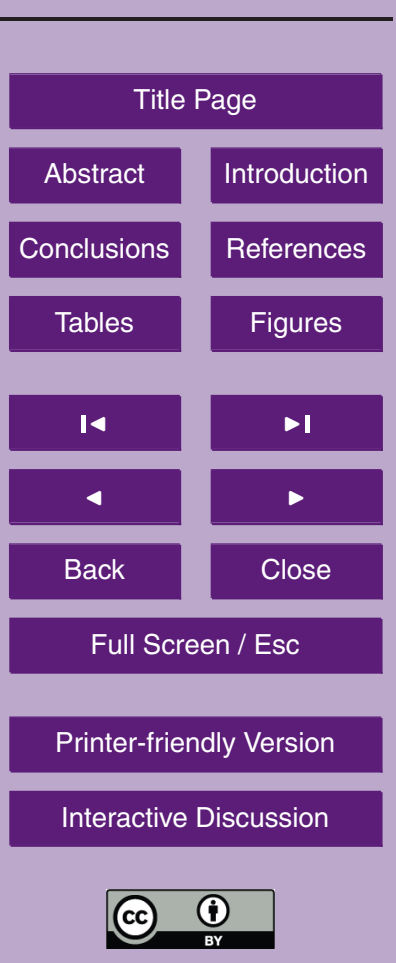


Peedee Belemnite (PDB) international standard and calibrated using the NBS-19 international standard. The precision, deduced from daily replicate measurements of an internal laboratory calcite standard (MACS1; $\delta^{13} \mathrm{C}=1.18 \%$ o, $\delta^{18} \mathrm{O}=-4.72 \%$ ), was better than $0.06 \%$ ofor $\delta^{13} \mathrm{C}$ and $0.07 \%$ for $\delta^{18} \mathrm{O}( \pm 1 \mathrm{~s})$. The oxygen fractionation fac5 tor (1.01025) at $25.0^{\circ} \mathrm{C}$ for calcite (Sharma and Clayton, 1964; Friedman and O'Neil, 1977) was adopted.

The isotopic results of Cytherissa lacustris shell calcite are presented in Table 1. Within the lower unit, $\delta^{13} \mathrm{C}$ was $0.5 \%$ - $2.0 \%$, with the average of $1.25 \%$, whereas $\delta^{18} \mathrm{O}$ fluctuated between $-7.0 \%$ and $-6.0 \%$, averaging $-6.5 \%$. The $\delta^{13} \mathrm{C}$ values increased 10 upward from the middle of the lower unit to the lower part of the transition unit to a maximum of about $3.0 \%$, then decreased abruptly to the middle of the transitional unit. The $\delta{ }^{18} \mathrm{O}$ values, in contrast, showed an abrupt increase throughout the upper part of the lower unit, and reached the maximum of about $-5.2 \%$ at the middle of the transitional unit.

\subsubsection{Lake water isotopes}

For evaluating the meteoric water contribution, we conducted an isotopic analysis of lake water recovered from water depth of $1 \mathrm{~m}$ at several kilometers offshore. For the isotopic measurement of inorganic carbon in lake waters, dissolved carbonates were fixed in barium carbonate by adding barium hydroxide to water samples immediately 20 after recovery from a water sampler. The barium carbonate, filtered out of the samples, was prepared for $\delta^{13} \mathrm{C}$ measurement. The oxygen isotope ratio of water was measured following Yoshida and Mizutani (1986) with slight modification. A $10 \mathrm{ml}$ of water sample was extracted into a polypropylene syringe through a needle. After removal of air bubbles, the volume of sample water was adjusted to $2.0 \mathrm{ml}$; then $8.0 \mathrm{~cm}^{3}$ (at $1 \mathrm{~atm}$.) of $\mathrm{CO}_{2}$ was introduced into a syringe. The syringe was maintained in a cool incubator at $25^{\circ} \mathrm{C}$ for $12 \mathrm{~h}$. The gas phase in the syringe was transferred into the evacuated line; then the $\mathrm{CO}_{2}$ was condensed using liquid nitrogen. Oxygen isotopes included in the condensed $\mathrm{CO}_{2}$ were measured using a mass spectrometer (Delta S; Finnigan MAT,

\section{Last-glacial to postglacial climate formation}

K. Minoura et al.

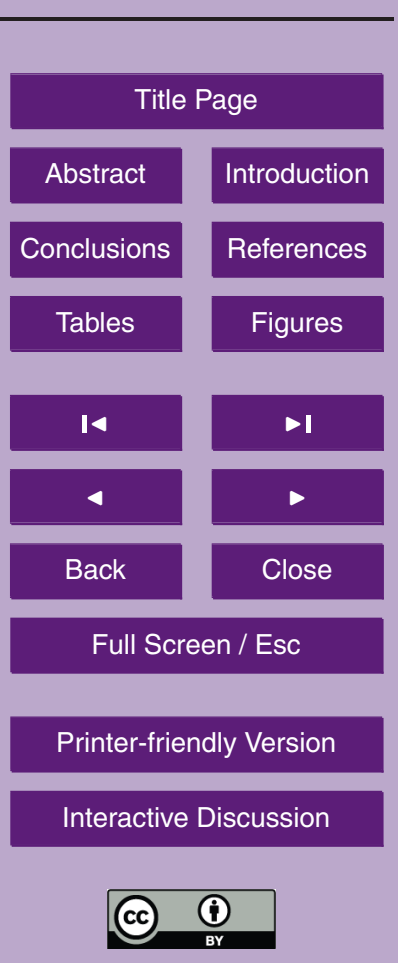


USA) in the manner described for the analysis of ostracod shell calcite isotopes.

The results of stable carbon and oxygen isotopic analysis of dissolved total carbon and water samples from Lake Hovsgol are as follows.

$\left(\delta^{13} \mathrm{C}_{\mathrm{PDB}}, \delta^{18} \mathrm{O}_{\mathrm{SMOW}}\right)=(-5.67,-8.53),(-5.61,-8.50),(-4.74,-8.47)$

\section{$5 \quad 5$ Age model}

Sediment samples from organic-rich horizons in the cores were submitted for accelerator mass spectrometer (AMS) radiocarbon dating. To avoid chemical and biological contamination, the samples were frozen immediately after the core was split. The ${ }^{14} \mathrm{C} /{ }^{13} \mathrm{C}$ ratio of sample graphite was determined using a tandetron accelerator mass 10 spectrometer (AMS, 4130; High Voltage Engineering Europa B.V.) at the Dating and Material Research Center of Nagoya University. After correction using the $\delta^{13} \mathrm{C}$ value of the sample, the ${ }^{14} \mathrm{C} /{ }^{13} \mathrm{C}$ ratio was converted to ${ }^{14} \mathrm{C}$ age. Watanabe et al. (2009) reported the AMS results. In this study, we used those radiocarbon ages to construct age models.

15 Some problems in the interpretation of radiocarbon ages of organic carbon are noteworthy. Three potential sources of error exist in the core ages: deposition of reworked organic materials, post-depositional contamination of the samples with younger or older carbon, and a reservoir effect caused by disequilibrium between the atmosphere and the water in which the organic carbon was produced. The sedimentary organic carbon was derived mostly from autochthonous algae (Nara et al., 2005). For that reason, the amount of terrestrial organic remnant material transported from the watershed was negligible. Considering the geological evidence of sediment lamination in the lower unit and the prevalence of oxygen deficiency because of the degradation of organic remains during increased surface productivity, it is probable that physical reworking and biological contamination of sediments was slight. We have no accurate information related to the reservoir effect. The lake water is well mixed because of sea-
$6,385-420,2010$

\section{Last-glacial to postglacial climate formation}

K. Minoura et al.

\section{Title Page}

Abstract Introduction

Conclusions

Tables References Figures
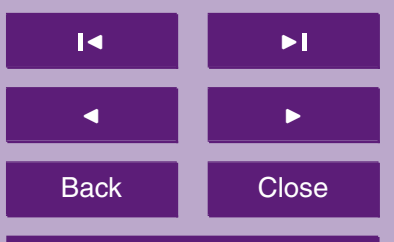

Back

Close

Printer-friendly Version

Interactive Discussion

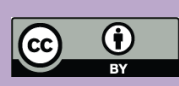


sonal cooling (Hayami et al., 2006), and the mixable situation of water column might have been retained during the interval of high surface productivity (upper unit). We interpreted that the reservoir effect in the lake was small.

The surface layer of core $\mathrm{X} 106$ yielded a non-zero age $\left(710 \pm 32^{14} \mathrm{C}\right.$ cal yr BP). Top5 most sediment loss during the core recovery was negligible in this case. It follows that the non-zero surface data might result from sediment grain motion by bottom surface currents. Prokopenko et al. (2007) recommended that age correction of around 500 years should be applied to obtain a reliable chronostratigraphy. Near surface samples of $\mathrm{X} 103$ dated $2482 \pm 28{ }^{14} \mathrm{C}$ cal yr BP, suggesting the occurrence of post-depositional 10 erosion of surface sediments. For this study, we converted all results of conventional ${ }^{14} \mathrm{C}$ ages to calendar years using the INTCAL04 dataset (Reimer et al., 2004). We applied a 500-yr correction prior to calibration of $A M S{ }^{14} \mathrm{C}$ ages; the results are shown in Table 3.

The ages of cores X103, X106, and X107 increase linearly with increasing burial 15 depth (linear depth-age relations) except for the interval of 21.5-22.0 cal ka BP, during which the sedimentation rates increased suddenly (Fig. 3b). Marked changes in paleoproxies such as stable isotopes and biogenic silica content cannot be identified at this time interval, and clay mineralogy and grain composition did not undergo changes. Consequently, the short-term rise in sedimentation rate implies that physical erosion of crustule surfaces by motion of glaciers increased greatly at this time period because of glacial development in mountainous regions. This implication suggests that the glaciation reached the maximum at around $22 \mathrm{cal} \mathrm{kaBP}$ in the provenance of runoff. Considering the linear sediment age-depth relation in the stratigraphic column deeper than $100 \mathrm{~cm}$ on core X106, we assumed the sedimentation rate of the layers underlying the horizon of increased sediment supply to have been the same as that of the layers overlying this event horizon. In Fig. 3, the chronostratigraphic profiles of the analytical data that were constructed are presented based on the age model using calibrated ages with age correction (Fig. 3c-k).
$6,385-420,2010$

\section{Last-glacial to postglacial climate formation}

K. Minoura et al.
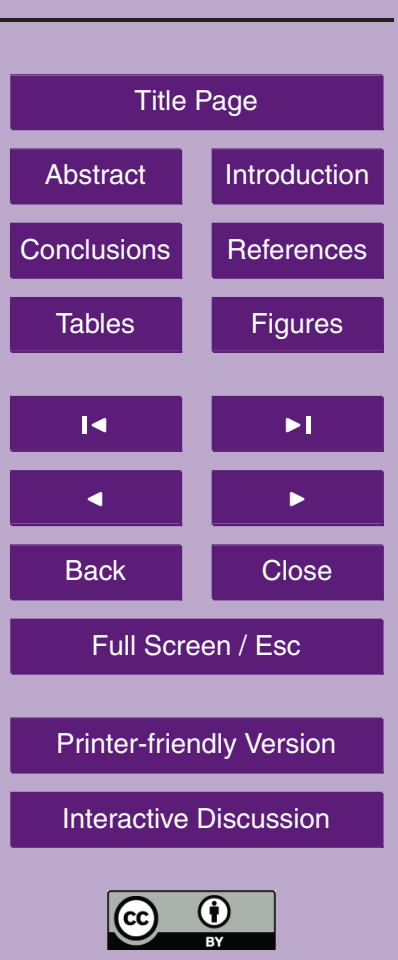


\section{Discussion}

Chemical and biochemical processes in soil environments are affected by climatic conditions, which therefore influence the rate of weathering as well as the weathering pathway. Biotite, an important precursor of the secondary clay minerals, changes into

5 illite, vermiculite, and smectite during weathering (Buol and Weed, 1991). The mineralogical results suggest that biotite derived from the metamorphic basement rocks progressively weathered to vermiculite and then to illite and smectite, a progression typical of arid and semi-arid regions (Ismail, 1970). Under warm and humid conditions, biotite is transformed to kaolinite via hydrobiotite or vermiculite (Buol and Weed, 10 1991). The weathering of biotite in the Baikal drainage basin followed the pathway from biotite to smectite through illite and vermiculite, and finally to kaolinite (Solotchina et al., 2009). Increased 10-Å peak widths at half height on X-ray diffractograms were attributable to an abundance of illite produced from altered biotite from metamorphic rocks (Sakai et al., 2005). We therefore interpret the calculated FWHM of 10-Å illite 15 peaks as indicative of weathering under climate changes. The peak width of illite in the short cores from the southern basin shows a decreasing tendency from around 20 cal ka BP (Fig. 3e), indicating the prevalence of humid conditions in the watershed in response to rising summer insolation (Fig. 3a). Clay-sized grains of well-crystallized minerals including quartz and biotite were the products of physical erosion of exposed rock surface by moving glaciers. Increased amounts of biotite and high clay content were characteristic of cold climate conditions (Sakai et al., 2005). Hydrolytic weathering prevailed in watersheds under warm and wet climate conditions, causing lowered clay contents and increased amounts of illite with decreased 10-Å peak width. The slight occurrence of clays (less than 1.0 weight \%) reflects the marked disappearance of glaciers at around 10 cal ka BP.

The oxygen isotopic results on ostracod shell calcite provide useful information for elucidating the reaction of Lake Hovsgol to changing water budget, water temperature, and aridification or humidification processes. Seasonal precipitation and glacial
6, 385-420, 2010

\section{Last-glacial to postglacial climate formation}

K. Minoura et al.

\section{Title Page}

Abstract

Introduction

Conclusions

References

Tables

Figures
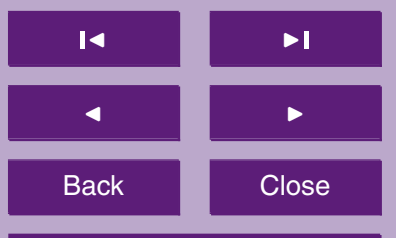

Back

Close

Printer-friendly Version

Interactive Discussion

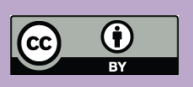


meltwaters are the main contributors of waters in the lake. Furthermore, $\delta^{18} \mathrm{O}$ ratios of source water are known to exert a great effect on oxygen isotopic composition of lake waters. Air temperatures and atmospheric pathways probably exert a heavy impact on oxygen isotopic composition of local precipitation in the continental interior. 5 Lake water cooling and warming are important factors influencing the mineralogical fixation of oxygen isotopes in waters. Water temperature, together with isotopic composition of source water, controls oxygen isotope fractionation on the occasion of carbonate deposition. The $\delta^{18} \mathrm{O}$ values of shell calcite increased rapidly during the last glacial-postglacial transition (Fig. 4g). Given the drastic lake-level rise at $15.4 \mathrm{cal} \mathrm{ka} \mathrm{BP}$ 10 (Prokopenko et al., 2005), the positive isotopic shift extending to $1.5 \%$ o does not reflect the net evaporative loss of lake water, but a decrease in temperature of lake water or supply of source water rich in heavy oxygen. The large south-north contrast in oxygen isotope ratios of winter precipitation reflects that the atmospheric moisture depleted in heavy oxygen is supplied by cooler air masses from the north (Siberian monsoon; 15 Fig. 1). Seasonal warm air masses (SE Asian monsoon) carry moisture that is rich in heavy oxygen to the continental interior.

A difference in isotopic response existed between the south (cores X103 and X106) and north (core X107) of the lake. The effect of heavy oxygen enrichment appeared in the southern lake ca. 3000 years earlier than in the case of northern lakes. Cores $20 \mathrm{X} 103$ and X106 show the occurrence of an abrupt decrease in clay concentrations at ca. 22 cal ka BP (immediately after the period of maximum glaciation), although the profile of the clay concentration in core X107 exhibits that high sediment influx was retained as late as ca. $16 \mathrm{cal} \mathrm{kaBP}$ in the northern lake (Fig. $4 \mathrm{~d}$ ). The supply of finegrained sediments reflects crustal denudation by moving glaciers. We interpreted that 25 fully developed glaciers existed in the provenance of runoff of the northern lake extending for more than 6000 years after the onset of glacial retreat in the drainage of the southern lake. This interpretation is consistent with the delivery of illite with broad $10-\AA$ peak width into the northern lake down to ca. 16 cal ka BP (Fig. 4e). High and steep ridges surround the northern lake, although dissected landforms are characteristic for
6, 385-420, 2010

\section{Last-glacial to postglacial climate formation}

K. Minoura et al.
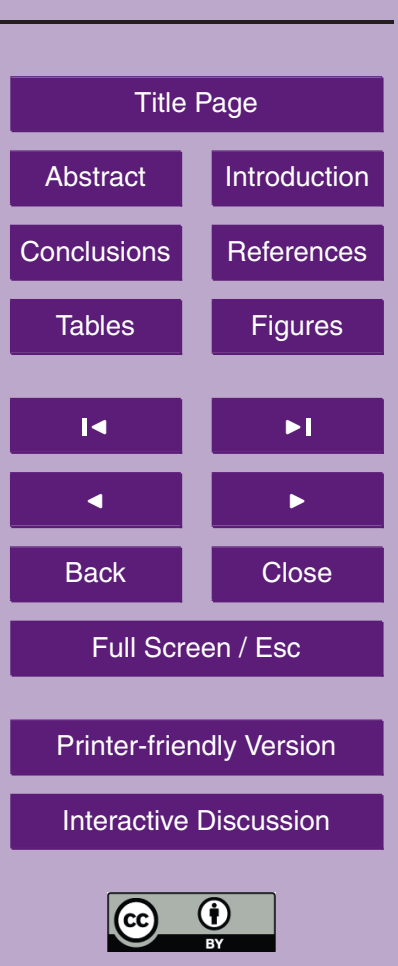
the catchment of the southern lake (Fig. 2). Consequently, the most plausible mechanism to explain the delay in isotopic response of the northern lake is the prolonged duration of developed glaciers in upstream areas. Considering the gradual narrowing of illite peak width (soilification) and the continuing supply of clastic minerals (glacial 5 retreat), as well as the occurrence of arboreal pollens (forestation), the heavy oxygen enrichment excludes the potential of lake-water cooling. Summertime precipitation from warm air masses is likely to favor the sufficient supply of water rich in ${ }^{18} \mathrm{O}$. Taken together, the positive shift in $\delta^{18} \mathrm{O}$ of the lake can be ascribed to the increased precipitation from air masses delivered by SE Asian monsoons. Our scenario is consistent 10 with the conclusion of Prokopenko et al. (2009), who designated that the positive $\delta^{18} \mathrm{O}$ shift is a signal of atmospheric moisture supply from warmer air masses.

The oxygen isotope ratio of calcite equilibrated with modern lake water (ca. 8.2-ca. $8.6 \%$ 。 SMOW) at $4.0^{\circ} \mathrm{C}$ worked out at -5.6 to $-6.0 \%$ PDB (Fig. $4 \mathrm{~g}$ ), which is very close to the values of present summer precipitation (Fig. 2). Given that the reaction of the lake to precipitation rich in heavy oxygen was responsible for summer insolation changes, it is suggested that the seasonal prevalence of warm air masses to the watershed reached the maximum at around $10 \mathrm{cal} \mathrm{ka} \mathrm{BP.} \mathrm{In} \mathrm{Fig.} \mathrm{4g,} \mathrm{we} \mathrm{propose} \mathrm{a} \mathrm{downward}$ tending profile of shell calcite $\delta^{18} \mathrm{O}$ ratios, which implies a prevailing condition of seasonal cooler air masses through the middle to late Holocene time. The negative ca. $201 \%$ shift in $\delta^{18} \mathrm{O}$ might be ascribed to the net decrease in seasonal precipitation from warm air masses.

The calcite carbon isotopes, which reflect the ${ }^{12} \mathrm{C}$ concentration at the lake bottom, showed a somewhat different trend in concentration. The $\delta{ }^{13} \mathrm{C}$ enrichment occurred in the southern lake immediately after the period of high sedimentation rate, approxi25 mately 4000 years earlier than the onset of a $\delta{ }^{13} \mathrm{C}$ rise in the northern lake. The $\delta{ }^{13} \mathrm{C}$ ratios reached the maximum at around $17 \mathrm{cal} \mathrm{ka} \mathrm{BP}$. The total carbonate $\delta^{13} \mathrm{C}$ ratios of modern lake water are $-4.7--5.7 \%$ PDB. It might be expected that a large depression of carbon isotope ratios occurred as a result of the increased light carbon $\left({ }^{12} \mathrm{C}\right)$ budget. Considering the increase in biogenic silica concentration after the carbon isotope shift

\section{Last-glacial to postglacial climate formation}

K. Minoura et al.
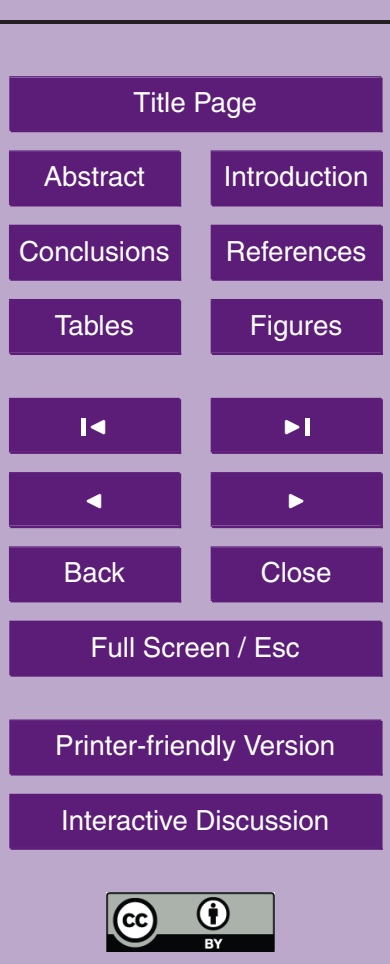
at $17-18 \mathrm{cal} \mathrm{kaBP}$, the ${ }^{12} \mathrm{C}$ enrichment in ostracod shells signifies enhanced aquatic production. This consequence demonstrates that the positive shift of $\delta^{12} \mathrm{C}$ signifies a net productivity loss in the lake, reflecting the overall decline of productivity there. Before the occurrence of the carbon isotope shift, the $\delta^{13} \mathrm{C}$ ratios of core $\mathrm{X} 107$ remained 5 at a low level (ca. 1\%。 PDB), suggesting that algal production was somewhat maintained in the northern lake. No frustule occurrence and extremely low biogenic-silica concentration (ca. 2.5\%: limit of detection) in core X107 reflect the surface productivity in the northern lake as contributed by phytoplankton without a skeletal framework.

The parallel trend of fluctuations in biogenic silica concentration (Fig. 4c) and total 10 frustules (Fig. 4h) suggests that the opaline silica originated mostly from diatoms. After reaching the maximum at $8-10 \mathrm{cal} k \mathrm{kP}$, these two records showed a downturn, and remained at a certain level since $7 \mathrm{cal}$ ka BP. The trend of aquatic production represented by the silica concentration is generally parallel to the reconstructed profile of summer insolation. It follows simply that algal blooming was responsible for the vari15 ation of solar energy. The narrowing of $10-\AA$ illite peak width continued for more than 7000 years after the carbon isotope shift, during which the peak width was reduced from 0.32 to 0.25 (Fig. 4e). Later, the full width fluctuated around 0.20 , which is mostly the same as values of illite included in highly weathered part of gravels in illuvial soils underlying the Selenga delta (Sakai et al., 2005). This mineralogical result indicates 20 progressive weathering of the watershed surface through the Holocene. The less advanced weathering in the catchment of the northern lake, as suggested by wider peaks of illite from core X107 than those of core X106, is attributable to the shorter approach to the site of grains settling from the source of clastics.

In reference to the carbon isotope shift to light carbon enrichment (Fig. 4f), the nutri17-18 cal ka BP. However, biological silica fixation was restricted in the latter half of the stage of the nutrient supply. Mechanical denudation and annual melting of mountain glaciers in the drainage basin provided Fe-rich and Mg-rich mica minerals to the lake. Iron is an indispensable element for photosynthetic metabolism and respiratory

6, 385-420, 2010

\section{Last-glacial to postglacial climate formation}

K. Minoura et al.

\section{Title Page}

Abstract

Introduction

Conclusions

References

Tables

Figures

14

DI

4

Back

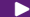

Close

\section{Full Screen / Esc}

Printer-friendly Version

Interactive Discussion

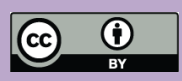


electron transport (e.g., nitrate reduction, chlorophyll synthesis, and detoxification of reactive oxygen species). Franck et al. (2000) ascertained using laboratory experiments that the silicate uptake ratio is lower in iron-rich incubation medium. It was interpreted that Fe addition promotes the growth of non-siliceous phytoplankton and 5 protoplasts of diatoms. Nara et al. (2005) investigated photosynthetic pigments in core samples from the Hovsgol Lake. Their analytical data suggest that the biomarkers that are indicative of green algae and cyanobacteria were present in the stage of non frustule-occurrence. Consequently, the increased input of mafic minerals produced by glacial denudation inhibited silica uptake by the phytoplankton group. The switch to 10 major production of diatoms was consistent with the reduction of sediment supply and the increased weathering of clays.

The pollen grains started to increase rapidly after $11 \mathrm{cal} k \mathrm{kBP}$. They reached the maximum during the ensuing 1000 years (Fig. $4 \mathrm{i}$ and j). Subsequently, the pollen concentration exhibited a steady decline towards the middle Holocene and remained low 15 thereafter, during which time the progressive chemical and biochemical weathering extended to the watershed. The rankness of herbaceous plants was inhibited until the maximum vegetation (Fig. 4k), although terrestrial weathering prevailed in the watershed (Fig. 4e). The integrated information related to paleoproxies reveals why the terrestrial and aquatic flora underwent explosive growth at the beginning of the Holocene.

In view of the response of plants to changes in summer insolation and nutrient supply, we infer that the leading cause of vegetation in the watershed was the utilization of solar energy, which affected the rate of weathering as well as the weathering pathway in soil layers through chemical and biochemical actions by terrestrial plants. This inference is supported by the assessment of the growth reaction of terrestrial flora for changing summer insolation.

The atmospheric moisture is supplied to inland areas beyond the average monsoon limit (Fig. 1), strongly depending on seasonal warming. Consequently, the enlargement of forests reflects a prevalence of vegetational merits in the watershed resulting from the extent of monsoonal circulation. The oxygen isotope results imply that the influence
$6,385-420,2010$

\section{Last-glacial to postglacial climate formation}

K. Minoura et al.

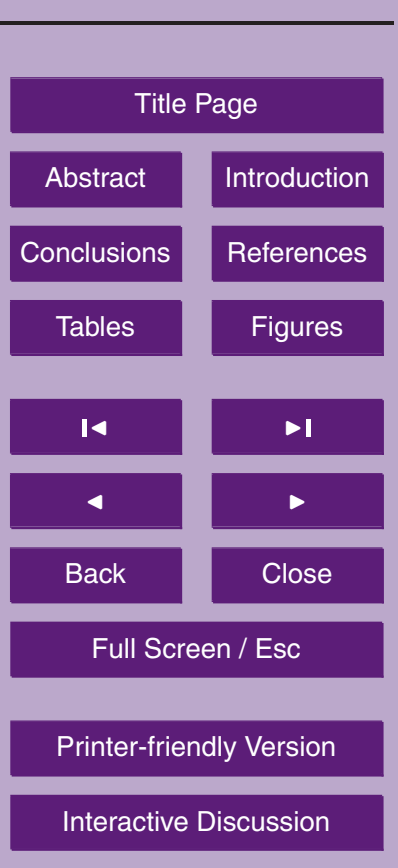

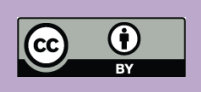


of Asian monsoons on the watershed reached a maximum value at around $10 \mathrm{cal}$ ka. BP and exhibited a decline thereafter. The moisture supply and consequent climatic amelioration promoted arboreal growth, and tree-covered lands stimulated the absorption of radiative energy. The positive feedback of solar energy utilization accelerated 5 atmospheric warming. Early in the Holocene, the pollen concentration decreased to one-third of the maximum, and remained at a very low level through the late Holocene. In view of the declining tendency of Holocene summer insolation, this scenario might explain the cause of floral retreat and the control of aquatic productivity.

Why were arboreal forests limited to growth before the Holocene? The record of 10 ostracod $\delta^{18} \mathrm{O}$ reveals the background of air mass movement. It is likely that atmospheric warming and wetting resulting from the seasonal extension of the SE Asian monsoon started at ca. $19 \mathrm{cal} \mathrm{ka} \mathrm{BP}$ and continued afterward. Based on the analogy of the proposed shell-calcite $\delta^{18} \mathrm{O}$-trend (Fig. $4 \mathrm{~g}$ ), summer precipitation increased quickly thereafter. However, the development of arboreal forests was extremely limited before the Holocene. The paleoproxy records from Lake Baikal reveal that arboreal forests started to growth at around ca. $19 \mathrm{cal}$ ka BP in the Baikal drainage basin (Horiuchi et al., 2000). Thus the limited growth of forests might have been attributable to vegetational acclimatization of arboreal tress to severe atmospheric conditions at elevated places. It is inferred from stratigraphic details of biogenic silica uptake that the aquatic productivity was responsible to some degree for the atmospheric humidity increase.

The water areas were affected only slightly by atmospheric fluctuations caused by the seasonal intrusion of cool air masses. The phytoplankton group in the surface layer was able to use enhanced radiation depending on the nutrient supply. Activated seasonal blooming might have accelerated vapor emissions on the lake surface in response to increasing summer radiation. It is likely that the net evaporative gain of atmospheric moisture from the expanded water surface during a high lake-level stand engender increasing vapor pressure of water. High dividing ridges surround the west and north of the narrow catchment, and the lake surface has an altitude greater than $1600 \mathrm{~m}$. The humidity increase probably caused atmospheric pressure lowering in this
$6,385-420,2010$

\section{Last-glacial to postglacial climate formation}

K. Minoura et al.

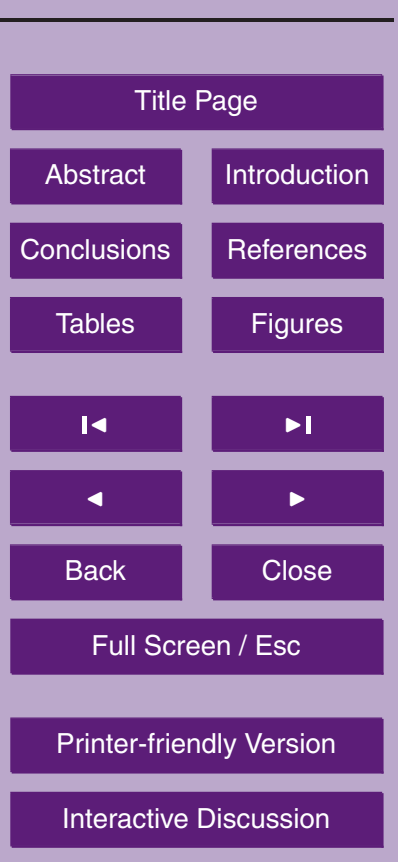


semi-closed basin at high altitudes, which allowed the summer monsoon to penetrate into the continental interior from the south, amplifying summer moisture supply to the watershed. The amplification improved the seasonal growth of arboreal trees under elevating summer insolation. The most probable scenario explaining the explosive ex5 pansion of forests in the Hovsgol watershed is the atmospheric humidity - pressure feedbacks under the influence of the summer insolation increase.

The retreat of arboreal forests, together with the diminishing algal production, implies that the northern extent of monsoonal circulation receded in response to the decrease of Holocene summer insolation (Herzschuh, 2006). The decreased utilization of solar energy reduced the atmospheric vapor pressure, which enhanced the seasonally advancing potential of cool air masses from the north. Furthermore, we suspect that the increased pressure gradient between north and south in the continental interior was the proximate cause of continental cooling in Eastern Asia.

\section{Concluding remarks}

15 The proxy records in cored sediments from Lake Hovsgol show that lacustrine conditions have fluctuated widely during the last $30 \mathrm{ka}$. The termination of glacial and stadial cooling and the subsequent prevalence of interglacial and interstadial warming in the watershed are consequences of solar forcing. The limnological evolution of the catchment area was linked closely with the mode of glacial retreat, which was consistent with the glacial-deglacial changes in summer insolation.

The oxygen isotope records of the ostracod shell calcite from the deglacial stratigraphic interval provide information related to the water budget and water temperature of the lake and source water characteristics. The $\delta^{18} \mathrm{O}$ values of shell calcite increased rapidly at the last glacial-postglacial transition. The narrowing $10-\AA$ illite peak width

(soilification) and the decreasing sediment supply (glacial retreat) exclude the possibility that cooling did not extend to the lake during this time interval. Given the occurrence of a drastic lake-level rise, the positive $1.5 \%$ shift in $\delta^{18} \mathrm{O}$ of ostracod calcite shells rec-
$6,385-420,2010$

\section{Last-glacial to postglacial climate formation}

K. Minoura et al.
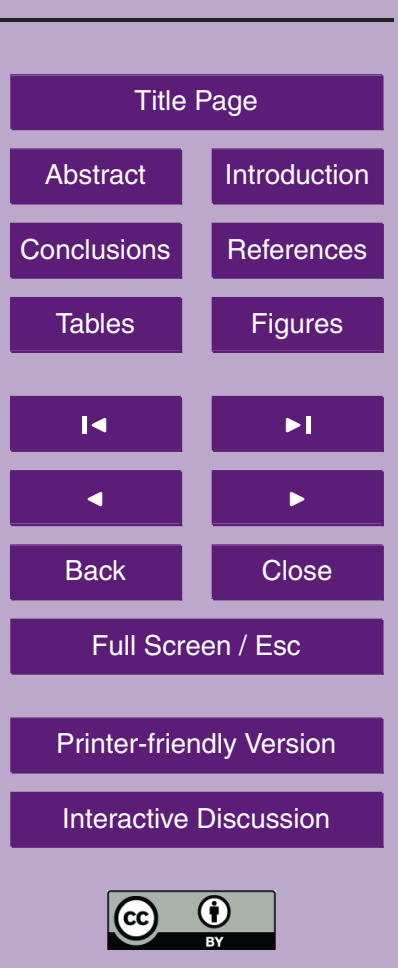
ognized at the transition implies a supply of heavy-oxygen-rich source water. As the present atmospheric circulation in the continental interior suggests, it is likely that cool air masses from the north supply isotopically light precipitation. Summertime atmospheric moisture transports isotopically heavy precipitation from the south to the conti5 nental interior. It is our interpretation that the positive shift in $\delta^{18} \mathrm{O}$ of the lake resulted from the increased precipitation from warm air masses delivered by the SE Asian monsoon. The proposed shell calcite $\delta^{18} \mathrm{O}$ profile, presenting a changing condition of air masses through the middle to late Holocene time, includes a negative ca. $1 \%$ isotopic shift, which can be ascribed to the net decrease in isotopically heavy precipitation from 10 warm air masses.

A difference was apparent in the isotopic response between the southern and northern areas of the lake, and in the effect of heavy oxygen enrichment that appeared in the southern lake ca. 3000 years earlier than in the northern lake. The supply of finegrained sediments reflects crustal denudation by moving glaciers. We interpreted that fully developed glaciers existed in the provenance of the runoff of the northern lake, extending for more than 6000 years after the onset of glacial retreat in the drainage of the southern lake. This interpretation is consistent with the delivery of illite with broad $10-\AA$ peak width into the northern lake down to ca. 16 cal ka BP. The most plausible mechanism to explain the delay in the isotopic response of the northern lake is the prolonged duration of mountain glaciers in upstream areas. In view of the advancing soilification and retreating glaciers, the heavy oxygen enrichment excludes the possibility of lake-water cooling. Summertime precipitation from warm air masses is likely to favor the sufficient supply of water rich in ${ }^{18} \mathrm{O}$. Consequently, the positive shift in $\delta^{18} \mathrm{O}$ of the lake can be ascribed to the increased summer precipitation from air masses delivered by the SE Asian monsoon.

Arboreal forests at high latitudes exerted an important influence on the atmospheric moisture cycle, possibly driving a positive feedback loop of humidification as radiation increased. The coniferous forest canopy can increase solar energy absorption. In addition, the seasonal growth of arboreal forests promoted the supply of moisture to the

$6,385-420,2010$

\section{Last-glacial to postglacial climate formation}

K. Minoura et al.
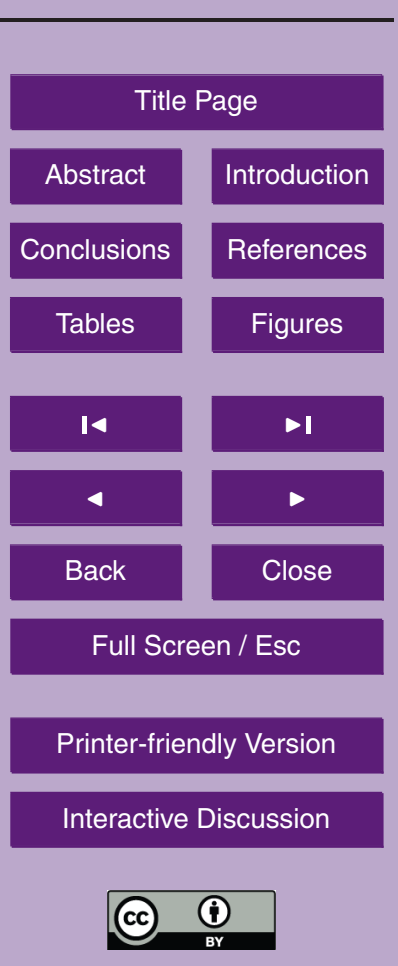
atmosphere, thereby elevating the water vapor level in air masses and lowering the air pressure. The deglacial retreat of cool air masses resulting from that atmospheric pressure decrease allowed the summer monsoon to penetrate into the continental interior, thereby amplifying the moisture supply. Our palynological data imply that the feedbacks 5 between moisture and vegetation were greatest at the beginning of the Holocene. It is inferred from the Holocene record of terrestrial flora that the rapid reduction of arboreal forests provoked the retreat of the northern extent of monsoonal circulation. The decreased solar energy utilization reduced the moisture supplied to the atmosphere, which allowed cool air masses to move south, giving rise to continental cooling in East10 ern Asia.

Arboreal forests were limited to growth before the Holocene, even though atmospheric warming and wetting attributable to the seasonal extension of summertime monsoon prevailed in the watershed. The rising lake-level caused expansion of the lake surface, leading to the evaporative input of moisture to the atmospheric in response to enhancing summer insolation. The humidity increase lowered the atmospheric pressure in the semi-closed basin at high altitudes, which allowed the summer monsoon to penetrate into the continental interior from the south, thereby amplifying the summer moisture supply to the watershed. That amplification improved the seasonal growth of arboreal trees under bright sunlight. The most probable scenario explaining the explosive expansion of forests in the Hovsgol watershed is the humidity-vegetation feedback under the control of the summer insolation increase.

Acknowledgements. We acknowledge financial assistance from the Japan Baikal Association (JABIRP). We thank K. Horiuchi for his coring effort in Lake Hovsgol. T. Sakai, Y. Kobayashi, and $\mathrm{T}$. Kegai were helpful during sample preparation and analyses.

$6,385-420,2010$

\section{Last-glacial to postglacial climate formation}

K. Minoura et al.

\section{Title Page}

Abstract Introduction

Conclusions References

Tables Figures
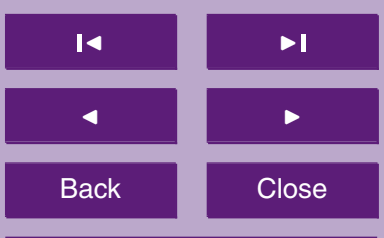

Back

Close

Full Screen / Esc

Printer-friendly Version

Interactive Discussion

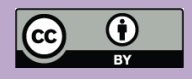




\section{References}

Batsyk, N., Scxhymeev, V. P., Cherkasov, A. E., and Samarin, A. V.: Hydrological and hydrographic characters, in: Natural conditions and resources of the Hovsgol Region in the Mongolian Peoples Republic, edited by: Sodnom, N., Losev, N. F., Nedra, Moscow, 185-206, 1976 (in Russian).

Buol, S. W. and Weed, S. B.: Saprolite-soil transformations in the piedmont and mountains of North Carolina, Geoderma, 51, 15-28, 1991.

Dykoski, C. A., Lawrence, E. R., Cheng, H., Yuan, D., Cai, Y., Zhang, M., Lin, Y., Qing, J., An, Z., and Revenaugh, J.: A high-resolution, absolute-dated Holocene and deglacial Asian monsoon record from Dongge Cave, China, Earth Planet Sc. Lett., 233, 71-86, 2005.

Faegri, K., Kaland, P. E., and Krzywinski, K.: Textbook of Pollen Analysis, 4th edn., Wiley, New York, USA, 328 pp., 1989.

Fedotov, A. P., Chebykin, E. P., Semenov, M. Yu., Vorobyova, S. S., Osipov, E. Yu., Golobokova, L. P., Pogodaeva, T. V., Zheleznyakova, T. O., Grachev, M. A., Tomrhuu, D., Oyunchimeg, Ts., Narantsetseg, Ts., Tomurtogoo, O., Dolgikh, P. T., Arsenyuki, M. I., and De Batist, M.: Changes in the volume and salinity of Lake Khubsugul (Mongolia) in response to global climate changes in the upper Pleistocene and Holocene, Palaeogeography, Palaeoclimatology, Palaeoecology, 209, 245-257, 2004.

Fowell, S. J. and Peck, J.: Data collected in Mongolia offers key clues to past climate, EOS, 78, 320-321, 1997.

Friedman, I. and O'Neil, J. R.: Compilation of stable isotope fractionation factors of geochemical interest, USGS Prof. Paper, 440-KK, 1977.

Franck, V. M., Brzezinski, M. A., Coale, K. H., and Nelson, D. M.: Iron and silicic acid concentrations regulate Si uptake north and south of the Polar Frontal Zone in the Pacific Sector of the Southern Ocean, Deep-Sea Res. II, 47, 3315-3338, 2000.

Gao, Y. X.: On some problems of Asian monsoon, "Some Questions about the East Asian Monsoon", Science Press, Beijing, 1-49, 1962.

Gordon, J. O.: An alternative to exotic spore or pollen addition in quantitative microfossil studies, Can. J. Earth Sci., 23, 102-106, 1986.

30 Hayami, Y., Kumagai, M., Maruo, M., Sekino, T., Tsujimura, S., and Urabe, J.: Review of some physical processes in Lake Hovsgol, in: The Geology, edited by: Goulden, C. E., Sitonikova, T., and Boldgiv, B., Biodiversity and Ecology of Lake Hovsgol (Mongolia), 115-124, Backhuys
6, 385-420, 2010

\section{Last-glacial to postglacial climate formation}

K. Minoura et al.

\section{Title Page}

Abstract

Introduction

Conclusions

References

Tables

Figures
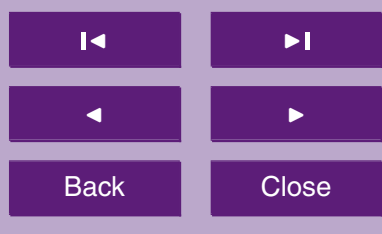

Back

Close

Printer-friendly Version

Interactive Discussion 
Publishers, Leiden, The Netherlands, 2006.

Herzschuh, U.: Palaeo-moisture evolution in monsoonal Central Asia during the last 50000 years, Quaternary Sci. Rev., 25, 163-178, 2006.

Horiuchi, K., Minoura, K., Hoshino, K., Oda T., Nakamura T., and Kawai T.: Paleoenvironmental history of Lake Baikal during the last 23000 years, Paleogeogr. Paleoclimatol. Paleoecol., 157, 95-108, 2000.

Ismail, F. T.: Biotite weathering and clay formation in arid and humid regions of California, Soil Sci., 109, 257-261, 1970.

Khursevich, G. K. and Prokopenko, A. A.: Diatom record from Lake Hovsgol, Mongolia, during the last $1 \mathrm{Ma}$ : the results from the HDP-04 drill core, Quatern. Int., 205, 84-97, 2009.

Kozhova, O. M., Shagdarsuren, O., Dashdorj, A., and Sodnom, N.: Atlas of Lake Hovsgol, Cartographic Ministry of USSR, 118 pp., 1989 (in Russian).

Krivonogov, S. K.: Late Cenozoic history of the Hovsgol area, in: The Geology, Biodiversity and Ecology of Lake Hovsgol (Mongolia), edited by: Goulden, C. E., Sitonikova, T., and Boldgiv,

15 B., Backhuys Publishers, Leiden, The Netherlands, 21-40, 2006.

Laskar, J., Robutel, P., Joutel, F., Gastineau, M., Correia, A. C. M., and Levrard, B.: A longterm numerical solution for the insolation quantities of the Earth, Astron. Astrophys., 428, 261-285, 2004.

Moore, D. M. and Reynolds Jr., R. C.: X-ray diffraction and the identification and analysis of clay minerals: 2nd edition, Oxford University Press, Oxford, 378 pp., 1997.

Mortlock, R. A. and Froelich, P. N.: A simple method for the rapid determination of biogenic opal in pelagic marine sediments, Deep-Sea Res., 36, 1415-1426, 1989.

Namkhaijantsan, G.: Climate of the Hovsgol Lake region, in: The Geology, edited by: Goulden, C. E., Sitonikova, T., and Boldgiv, B., Biodiversity and Ecology of Lake Hovsgol (Mongolia), Backhuys Publishers, Leiden, The Netherlands, 63-76, 2006.

Nara, F., Tani, Y., Soma, Y., Soma, M., Naraoka, H., Watanabe, T., Horiuchi, K., Kawai, T., Oda, T., and Nakamura, T.: Response of phytoplankton productivity to climate change recorded by sedimentary photosynthetic pigments in Lake Hovsgol (Mongolia) for the last 23000 years, Quatern. Int., 136, 71-81, 2005.

so Poberezhnaya, A. E., Fedotov, A. P., Sitnikova, T. Y., Semenov, M. Y., Ziborova, G. A., Otinova, E. L., and Khabuev, A. V.: Paleoecological and paleoenvironmental record of the Late Pleistocene record of Lake Khubsugul (Mongolia) based on ostracod remains, J. Paleolimnol., 36, 133-149, 2006.
$6,385-420,2010$

\section{Last-glacial to postglacial climate formation}

K. Minoura et al.

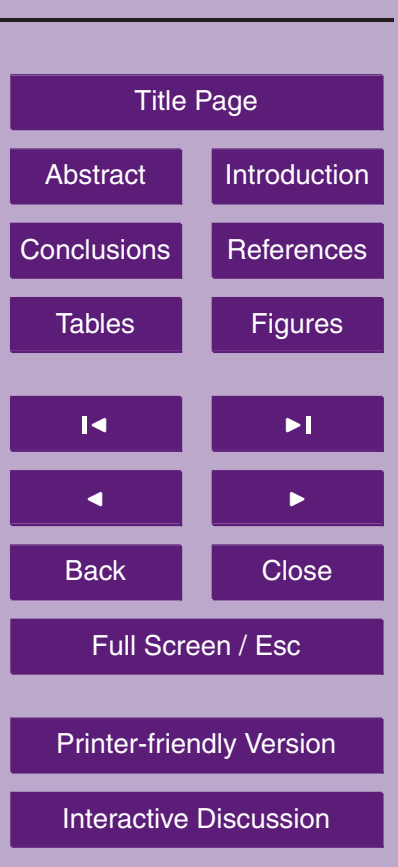


Porter, S. C. and An, Z.: Correlation between climate events in the North Atlantic and China during the last glaciations, Nature, 375, 305-308, 1995.

Prokopenko, A. A., Hinnov, L. A., Williams, D. F., and Kuzmin, M. I.: Orbital forcing of continental climate during the Pleistocene: a complete astronomically tuned climatic record from Lake Baikal, SE Siberia, Quaternary Sci. Rev., 25, 3431-3457, 2006.

Prokopenko, A. A., Kuzmin, M. I., Williams, D. F., Gelety, V. F., Kalmychkov, G. V., Gvozdkov, A. N., and Solotchin, P. A.: Basin-wide sedimentation changes and deglacial lake-level rise in the Hovsgol Basin, NW Mongolia, Quatern. Int., 136, 59-69, 2005.

Prokopenko, A. A., Khursevich, G. K., Bezurkova, E. V., Kuzmin, M. I., Boes, X., Williams, D. F., Fedenya, S. A., Kulagina, N. V., Letunova, P. P., and Abzaeva, A. A.: Paleoenvironmental proxy records from Lake Hovsgol, Mongolia, and a synthesis of Holocene climate change in the Lake Baikal watershed, Quaternary Res., 68, 2-17, 2007.

Prokopenko, A. A. and Bonvento, V. J.: Carbonate stable isotope signals in the 1-Ma sedimentary record of the HDP-04 drill core from Lake Hovsgol, NW Mongolia, Quatern. Int., 205, 15 53-64, 2009.

Reimer, P. J., M. G. L. Baillie, E. Bard, A. Bayliss, J. W. Beck, C. J. H. Bertrand, P. G., Blackwell, C. E. Buck, G. S. Burr, K. B. Cutler, P. E. Damon, R. L. Edwards, R. G. Fairbanks, M. Friedrich, T. P. Guilderson, A. G. Hogg, K. A. Hughen, B. Kromer, G. McCormac, S. Manning, C. B. Ramsey, R. W. Reimer, S. Remmele, J. R. Southon, M. Stuiver, S. Talamo, F. W. Taylor, J. van der Plicht, and C. E.: Weyhenmeyer IntCal04 terrestrial radiocarbon age calibration, 0-25 cal kyr BP, Radiocarbon, 46, 1029-1058, 2004.

Sakai, T., Minoura, K., Soma, M., Tani Y., Tanaka, A., Nara, F., Itoh, N., and Kawai, T.: Influence of climate fluctuation on clay formation in the Baikal drainage basin, J. Paleolimnol., 33, 105$121,2005$.

San'kov, V. A., Miroshnichenko, A. I., Parfeevets, A. V., and Arzhannikova, A. V.: New data on Late Cenozoic tectonic stress fields in the Hovsgol region, Mongolia, Dokl. Earth Sci., 388, 30-33, 2003(in Russian).

Santrock, J., Studley, S. A., and Hayes, J. M.: Isotopic analysis based on the mass spectrum of carbon dioxide, Anal. Chem., 57, 1444-1448, 1985.

30 Sharma, T. and Clayton, R. N.: Oxygen Analyses of Minerals and Oxides, Anal. Chem., 36, 2001-2002, doi:10.1021/ac60216a036, 1964.

Solotchina, E. P., Prokopenko, A. A., Kuzmin, M. I., Solotchin, P. A., and Zhdanova, A. N.: Climate signals in sediment mineralogy of Lake Baikal and Lake Hovsgol during the LGM - 
Holocene transition and the 1-Ma carbonate record from the HDP-04 drill core, Quatern. Int., 205, 38-52, 2009.

Stuiver, M., Reimer, R. J. and Reimer, R. W.: CALIB 5.0. [WWW program and documentat], Quaternary Research Center, University of Washington, Seattle, available at: http://radiocarbon.pa.qub.ac.uk/calib/calib.html, 2005.

Watanabe, T., Nakamura, T., Watanabe, N. F., Kakegawa, T., Horiuchi, K., Senda, R., Oda, T., Nishimura, M., Inoue, M. G., and Kawai, T.: High-time resolution AMS 14C data sets for Lake Baikal and Lake Hovsgol sediment cores: Changes in radiocarbon age and sedimentation rates during the transition from the last glacial to the Holocene, Quatern. Int., 205, 12-20, 2009.

Yoshida, N. and Mizutani, Y.: Preparation of carbon dioxide for Oxygen-18 determination of water by using a plastic syringe, Anal. Chem., 58, 1273-1275, 1986.
6, 385-420, 2010

\section{Last-glacial to postglacial climate formation}

K. Minoura et al.

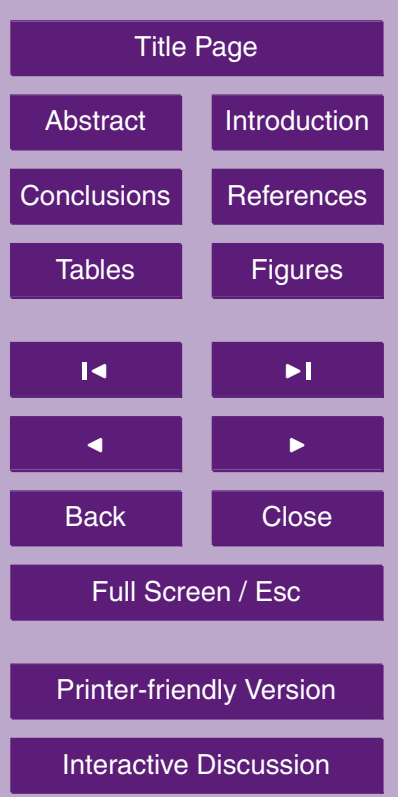


Table 1. Mineralogical and geochemical results on cores X103, X106, and X107. BioSi: biogenic silica, FWHM: full width at half maximum of $10-\AA ̊$ illite peaks.

\begin{tabular}{|c|c|c|c|c|c|c|c|}
\hline Core and sample & $\begin{array}{l}\text { Depth } \\
\mathrm{cm}\end{array}$ & $\begin{array}{c}\text { Age } \\
\text { years B.P. }\end{array}$ & $\begin{array}{c}\text { BioSi } \\
\text { content } \\
\text { weight \% }\end{array}$ & $\begin{array}{c}\text { Clay } \\
\text { FWHM } \\
\text { volume } \%\end{array}$ & $\begin{array}{c}\text { calcite isotope } \\
\AA\end{array}$ & $\begin{array}{l}\text { Ostracod shell } \\
\delta^{13} \mathrm{C} \% \text { PDB }\end{array}$ & $\delta^{18} \mathrm{O} \%$ PDB \\
\hline X103-1-01 & 1.25 & 1939.00 & 5.34 & 1.37 & & & \\
\hline X103-1-02 & 3.75 & 9460.59 & 4.99 & 0.86 & & & \\
\hline X103-1-03 & 6.25 & 10420.69 & 3.49 & 1.98 & & & \\
\hline X103-1-04 & 8.75 & 11380.80 & 3.01 & 3.69 & & & \\
\hline X103-1-05 & 11.25 & 12340.90 & 3.33 & 2.67 & & & \\
\hline X103-1-06 & 13.75 & 13301.00 & 3.09 & 3.22 & & & \\
\hline X103-1-07 & 16.25 & 14121.40 & 3.00 & 10.01 & 0.3076 & & \\
\hline X103-1-08 & 18.75 & 14941.80 & 2.84 & 11.23 & & & \\
\hline X103-1-09 & 21.25 & 15762.20 & 2.67 & 10.27 & 0.3075 & & \\
\hline X103-1-10 & 23.75 & 16582.60 & 2.33 & 11.06 & & & \\
\hline X103-1-12 & 28.75 & 17815.55 & 2.18 & 10.18 & & & \\
\hline X103-1-13 & 31.25 & 18228.10 & 2.54 & 7.71 & 0.3519 & & \\
\hline X103-1-14 & 33.75 & 18640.65 & 2.23 & 8.13 & & & \\
\hline X103-1-15 & 36.25 & 19053.20 & 2.30 & 11.41 & 0.3266 & & \\
\hline X103-1-16 & 38.75 & 19465.75 & 2.25 & 11.21 & & & \\
\hline X103-1-17 & 41.25 & 19878.30 & 2.32 & 14.50 & 0.3609 & & \\
\hline X103-1-18 & 43.75 & 20290.85 & 2.69 & 13.65 & & & \\
\hline X103-1-19 & 46.25 & 20703.40 & 2.09 & 11.88 & 0.3689 & & \\
\hline X103-1-20 & 48.75 & 21115.95 & 2.43 & 14.23 & & & \\
\hline X103-1-22 & 53.75 & 21595.51 & 2.27 & 15.82 & & & \\
\hline X103-1-23 & 56.25 & 21662.52 & 2.43 & 16.03 & 0.3429 & & \\
\hline X103-1-24 & 58.75 & 21729.53 & 2.27 & 15.12 & & & \\
\hline X103-1-25 & 61.25 & 21796.54 & 2.45 & 19.64 & 0.3480 & & \\
\hline X103-1-26 & 63.75 & 21863.55 & 2.19 & 19.88 & & 1.514 & -6.270 \\
\hline X103-1-27 & 66.25 & 21930.56 & 2.47 & 19.12 & 0.3348 & 1.306 & -6.342 \\
\hline X103-1-28 & 68.75 & 21997.57 & 2.40 & 19.19 & & 1.211 & -6.437 \\
\hline X103-1-29 & 71.25 & 22064.58 & 2.67 & 17.17 & 0.3382 & 1.408 & -6.427 \\
\hline $\mathrm{X} 103-1-30$ & 72.75 & 22104.78 & 2.60 & 17.24 & & & \\
\hline X103-2-01 & 74.25 & 22144.99 & 2.39 & 12.03 & 0.3260 & 1.074 & -6.590 \\
\hline \multicolumn{8}{|l|}{ X103-2-02 } \\
\hline X103-2-03 & 79.25 & 22624.55 & 2.42 & 18.26 & 0.3666 & 0.656 & -6.825 \\
\hline X103-2-04 & 81.75 & 23037.10 & 2.60 & 19.89 & & 1.127 & -6.763 \\
\hline X103-2-05 & 84.25 & 23449.65 & 3.41 & 18.19 & 0.2964 & 1.037 & -6.862 \\
\hline X103-2-06 & 86.75 & 23862.20 & 2.66 & 16.70 & & 1.305 & -6.316 \\
\hline X103-2-07 & 89.25 & 24274.75 & 2.41 & 16.39 & 0.3025 & 1.806 & -6.020 \\
\hline X103-2-08 & 91.75 & 24687.30 & 2.19 & 18.93 & & 1.160 & -6.130 \\
\hline X103-2-09 & 94.25 & 25099.85 & 2.16 & 18.68 & 0.3250 & 1.087 & -6.548 \\
\hline X103-2-10 & 96.75 & 25512.40 & 2.28 & 17.59 & & 0.980 & -6.355 \\
\hline $\mathrm{X} 103-2-11$ & 99.25 & 25924.95 & 2.68 & 17.03 & 0.3338 & 0.720 & -6.893 \\
\hline \multicolumn{8}{|l|}{ X103-2-12 } \\
\hline X103-2-13 & 104.25 & 26750.05 & 2.88 & 19.85 & 0.3508 & 1.527 & -6.266 \\
\hline X103-2-14 & 106.75 & 27162.60 & 2.72 & 16.49 & & & \\
\hline X103-2-15 & 109.25 & 27575.15 & 2.47 & 14.35 & 0.3445 & 1.652 & -6.236 \\
\hline X103-2-16 & 111.75 & 27987.70 & 2.07 & 16.97 & & 1.092 & -6.867 \\
\hline X103-2-17 & 114.25 & 28400.25 & 1.94 & 17.80 & & 1.274 & -6.404 \\
\hline \multicolumn{8}{|l|}{ X103-2-18 } \\
\hline X103-2-19 & 118.60 & 29118.09 & 3.07 & 15.58 & & 1.533 & -6.005 \\
\hline
\end{tabular}

$6,385-420,2010$

\section{Last-glacial to postglacial climate formation}

K. Minoura et al.

Title Page

\section{Abstract \\ Introduction \\ Conclusions \\ References}

Tables

Figures
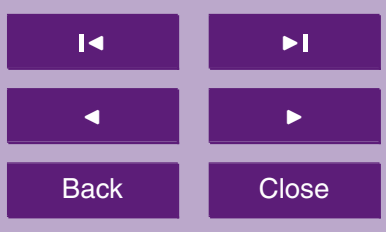

Back

Close

\section{Full Screen / Esc}

Printer-friendly Version

Interactive Discussion

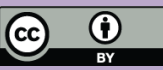


Table 1. Continued.

\begin{tabular}{|c|c|c|c|c|c|c|c|}
\hline \multirow[b]{2}{*}{$\mathrm{X} 106-1-01$} & \multirow[b]{2}{*}{0.75} & \multirow[b]{2}{*}{149.50} & \multicolumn{3}{|c|}{ Blank space: not determined } & \multicolumn{2}{|c|}{ Cytherissa lacustris } \\
\hline & & & 7.50 & 0.01 & 0.1331 & & \\
\hline$X 106-1-02$ & 2.25 & 419.63 & 10.02 & 0.42 & & & \\
\hline X106-1-03 & 3.75 & 689.75 & 9.53 & 0.52 & 0.2096 & & \\
\hline X106-1-04 & 5.25 & 959.88 & 7.67 & & & & \\
\hline X106-1-06 & 8.25 & 1598.55 & 8.38 & 0.47 & 0.1457 & & \\
\hline X106-1-07 & 9.75 & 1967.10 & 6.54 & & 0.1661 & & \\
\hline X106-1-08 & 11.25 & 2335.65 & 8.81 & 0.43 & & & \\
\hline X106-1-09 & 12.75 & 2704.20 & 8.58 & 0.20 & 0.1870 & & \\
\hline X106-1-10 & 14.25 & 3072.75 & 9.72 & 0.41 & & & \\
\hline X106-1-11 & 15.75 & 3441.30 & 8.68 & 0.20 & 0.1794 & & \\
\hline X106-1-12 & 17.25 & 3809.85 & 7.58 & 0.01 & & & \\
\hline X106-1-13 & 18.75 & 4178.40 & 7.73 & 0.05 & 0.1803 & & \\
\hline X106-1-14 & 20.25 & 4546.95 & 8.14 & 0.29 & & & \\
\hline X106-1-15 & 21.75 & 4915.50 & & 0.32 & & & \\
\hline X106-1-16 & 23.25 & 5331.60 & 8.59 & 0.32 & 0.2364 & & \\
\hline X106-1-17 & 24.75 & 5747.70 & 9.67 & 0.33 & 0.2127 & & \\
\hline X106-1-18 & 26.25 & 6163.80 & 8.35 & 0.40 & & & \\
\hline X106-1-19 & 27.75 & 6579.90 & 9.97 & 0.44 & 0.2046 & & \\
\hline X106-1-20 & 29.25 & 6996.00 & 11.38 & 0.36 & & & \\
\hline X106-1-21 & 30.75 & 7412.10 & 9.75 & 0.49 & & & \\
\hline X106-1-22 & 32.25 & 7828.20 & 8.12 & 0.28 & & & \\
\hline X106-1-23 & 33.75 & 8244.30 & 12.42 & 0.59 & 0.1756 & & \\
\hline$X 106-1-24$ & 35.25 & 8660.40 & 15.30 & 0.65 & & & \\
\hline X106-1-26 & 38.25 & 9522.60 & 12.39 & 1.03 & 0.2321 & & \\
\hline X106-1-27 & 39.75 & 9968.70 & 10.91 & 0.72 & 0.2296 & & \\
\hline X106-1-28 & 41.25 & 10414.80 & 9.80 & 0.89 & & & \\
\hline X106-1-29 & 42.75 & 10860.90 & 4.11 & 1.44 & 0.2842 & & \\
\hline X106-1-30 & 44.25 & 11307.00 & 7.13 & 0.92 & & & \\
\hline X106-1-31 & 45.75 & 11753.10 & 4.24 & 1.25 & 0.2283 & & \\
\hline X106-1-32 & 47.25 & 12199.20 & 4.10 & 3.66 & & & \\
\hline X106-1-33 & 48.75 & 12645.30 & 3.63 & 3.69 & 0.3058 & & \\
\hline$X 106-1-34$ & 50.25 & 13091.40 & 3.74 & 4.75 & 0.2733 & & \\
\hline$X 106-1-36$ & 53.25 & 14016.55 & 3.97 & 4.15 & & & \\
\hline X106-1-37 & 54.75 & 14495.60 & 4.11 & 7.19 & 0.3399 & 1.932 & -4.765 \\
\hline X106-1-38 & 56.25 & 14974.65 & 3.81 & 7.39 & & & \\
\hline X106-1-39 & 57.75 & 15453.70 & 3.24 & 7.81 & 0.3242 & 2.592 & -5.035 \\
\hline X106-1-40 & 59.25 & 15932.75 & 2.94 & 7.41 & & & \\
\hline X106-1-41 & 60.75 & 16411.80 & 2.40 & 6.74 & 0.3239 & 2.794 & -5.157 \\
\hline X106-1-42 & 62.25 & 16890.85 & 2.40 & 8.07 & & & \\
\hline X106-1-43 & 63.75 & 17369.90 & 2.27 & 7.61 & 0.3074 & 3.035 & -5.045 \\
\hline X106-1-44 & 65.25 & 17848.95 & 2.51 & 8.19 & & 2.722 & -5.558 \\
\hline X106-1-46 & 68.25 & 18694.78 & 2.49 & 8.93 & 0.3605 & 2.676 & -6.343 \\
\hline X106-1-47 & 69.75 & 19061.57 & 2.84 & 9.68 & 0.3275 & 2.090 & -6.259 \\
\hline X106-1-48 & 71.25 & 19428.35 & 2.43 & 10.44 & & 2.186 & -6.632 \\
\hline X106-2-01 & 73.75 & 20017.64 & 2.72 & 9.62 & 0.3712 & 2.188 & -6.441 \\
\hline X106-2-02 & 75.25 & 20358.01 & 2.79 & 16.96 & & 1.796 & -6.394 \\
\hline X106-2-03 & 76.75 & 20698.39 & 2.97 & 13.49 & 0.3621 & 2.217 & -6.354 \\
\hline X106-2-04 & 78.25 & 21038.76 & 2.54 & 17.93 & & & \\
\hline
\end{tabular}

6, 385-420, 2010

\section{Last-glacial to postglacial climate formation}

K. Minoura et al.

Title Page
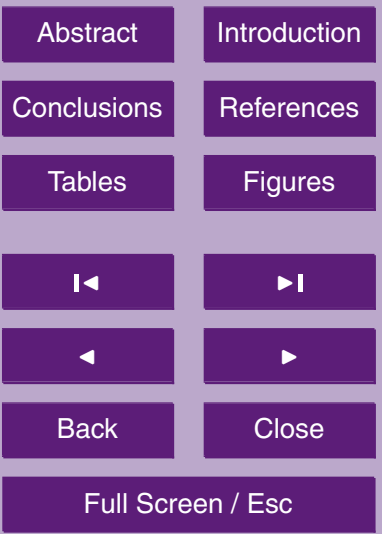

Printer-friendly Version

Interactive Discussion

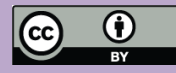


Table 1. Continued.

\begin{tabular}{|c|c|c|c|c|c|c|c|}
\hline X106-2-05 & 79.75 & 21379.13 & 2.73 & 20.16 & 0.4068 & 1.710 & -6.525 \\
\hline X106-2-07 & 82.75 & 21782.65 & 3.05 & 18.05 & 0.3859 & 1.653 & -6.497 \\
\hline X106-2-08 & 84.25 & 21845.80 & 2.87 & 19.04 & & 1.357 & -6.345 \\
\hline X106-2-09 & 85.75 & 21908.95 & 3.13 & 19.05 & 0.3395 & 1.590 & -6.443 \\
\hline X106-2-10 & 87.25 & 21972.10 & 2.74 & 18.77 & & 1.655 & -6.145 \\
\hline X106-2-11 & 88.75 & 22035.25 & 2.97 & 21.76 & 0.3962 & 1.134 & -6.116 \\
\hline X106-2-12 & 90.25 & 22098.40 & 2.83 & 20.78 & & & \\
\hline X106-2-13 & 91.75 & 22161.55 & 3.05 & 21.27 & 0.3566 & 1.790 & -6.364 \\
\hline X106-2-14 & 93.25 & 22224.70 & 2.82 & 21.74 & & 1.660 & -6.387 \\
\hline X106-2-15 & 94.75 & 22287.85 & 3.08 & 21.73 & 0.3832 & 1.123 & -6.542 \\
\hline X106-2-17 & 97.75 & 22695.35 & 2.62 & 20.73 & 0.4501 & 1.484 & -6.387 \\
\hline X106-2-18 & 99.25 & 23039.70 & 3.06 & 23.02 & & 0.536 & -6.687 \\
\hline X106-2-19 & 100.75 & 23384.05 & 2.95 & 22.70 & 0.4045 & & \\
\hline X106-2-20 & 102.25 & 23728.40 & 3.21 & 22.58 & & 0.790 & -6.472 \\
\hline X106-2-21 & 103.75 & 24072.75 & 2.78 & 21.42 & 0.4243 & 0.344 & -6.648 \\
\hline X106-2-22 & 105.25 & 24417.10 & 2.81 & 22.93 & & 1.086 & -6.504 \\
\hline X106-2-23 & 106.75 & 24761.45 & 2.57 & 20.65 & 0.3572 & 1.507 & -6.019 \\
\hline X106-2-24 & 108.25 & 25105.80 & 2.47 & 18.15 & & & \\
\hline X106-2-25 & 109.75 & 25450.15 & 2.69 & 19.04 & 0.3950 & 0.799 & -6.483 \\
\hline X106-2-27 & 112.75 & 26134.87 & 2.44 & 19.78 & 0.3910 & 0.355 & -6.278 \\
\hline X106-2-28 & 114.25 & 26475.24 & 2.66 & 19.87 & & 0.536 & -6.498 \\
\hline X106-2-29 & 115.75 & 26815.61 & 2.49 & 17.08 & 0.3980 & 0.427 & -6.807 \\
\hline X106-2-30 & 117.25 & 27155.99 & 2.80 & 22.13 & & 0.335 & -6.690 \\
\hline X106-2-31 & 118.75 & 27496.36 & 2.57 & 22.06 & 0.3461 & 1.022 & -6.201 \\
\hline X106-2-32 & 120.25 & 27836.73 & 2.40 & 15.20 & & 2.018 & -5.948 \\
\hline X106-2-33 & 121.75 & 28177.10 & 2.41 & 17.02 & 0.3748 & 1.722 & -5.900 \\
\hline X106-2-34 & 123.25 & 28517.47 & 2.25 & 20.45 & & 0.996 & -6.192 \\
\hline X106-2-35 & 124.75 & 28857.84 & 2.34 & 20.42 & 0.3550 & 1.127 & -6.217 \\
\hline \multirow{2}{*}{ X106-2-36 } & 126.25 & 29198.21 & 2.08 & 18.40 & 0.3062 & 1.260 & -6.103 \\
\hline & 127.75 & 29538.59 & & 17.59 & & & \\
\hline \multirow[t]{2}{*}{$X 106-2-38$} & 129.40 & 29912.99 & 2.05 & & & 0.827 & -6.143 \\
\hline & & & \multicolumn{3}{|c|}{ Blank space: not determined } & \multicolumn{2}{|c|}{ Cytherissa lacustris } \\
\hline & & & $\mathrm{BioSi}$ & Clay & & Ostracod shell & \\
\hline Core and sample & $\begin{array}{l}\text { Depth } \\
\mathrm{cm}\end{array}$ & $\begin{array}{c}\text { Age } \\
\text { years B.P. }\end{array}$ & $\begin{array}{l}\text { content } \\
\text { weight } \%\end{array}$ & $\begin{array}{c}\text { FWHM } \\
\text { volume \% }\end{array}$ & $\begin{array}{c}\text { calcite isotope } \\
\AA\end{array}$ & $\delta^{13} \mathrm{C} \%$ PDB & $\delta^{18} \mathrm{O} \%$ PDB \\
\hline X107-1-01 & 1.25 & 200.90 & 9.98 & & & & \\
\hline X107-1-02 & 3.75 & 602.71 & 9.40 & 0.21 & & & \\
\hline X107-1-03 & 6.25 & 1004.52 & 9.30 & 0.75 & & & \\
\hline X107-1-04 & 8.75 & 1406.33 & 10.13 & 0.36 & 0.2371 & & \\
\hline X107-1-05 & 11.25 & 1808.14 & 10.05 & 0.08 & & & \\
\hline X107-1-06 & 13.75 & 2209.95 & 8.87 & 0.41 & 0.2954 & & \\
\hline X107-1-07 & 16.25 & 2611.76 & 8.40 & 0.05 & & & \\
\hline X107-1-08 & 18.75 & 3013.57 & 8.63 & 0.80 & 0.2398 & & \\
\hline X107-1-09 & 21.25 & 3415.38 & 7.97 & 0.29 & & & \\
\hline X107-1-10 & 23.75 & 3817.19 & 7.13 & 0.29 & 0.2969 & & \\
\hline X107-1-11 & 26.25 & 4219.00 & 7.70 & & & & \\
\hline $\mathrm{X} 107-1-12$ & 28.75 & 4920.52 & 8.45 & 0.53 & 0.2447 & & \\
\hline X107-1-13 & 31.25 & 5622.03 & 8.82 & 0.2 & & & \\
\hline X107-1-14 & 33.75 & 6323.55 & 8.25 & 0.63 & 0.2602 & & \\
\hline
\end{tabular}

6, 385-420, 2010

\section{Last-glacial to postglacial climate formation}

K. Minoura et al.

\section{Title Page}

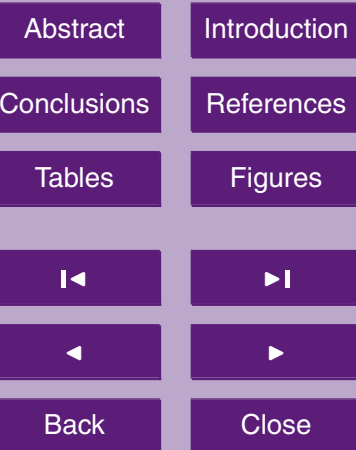

\section{Full Screen / Esc}

Printer-friendly Version

Interactive Discussion

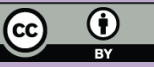


Table 1. Continued.

6, 385-420, 2010

\begin{tabular}{|c|c|c|c|c|c|c|c|}
\hline X107-1-15 & 36.25 & 7025.06 & 5.85 & 0.69 & & & \\
\hline$X 107-1-16$ & 38.75 & 7726.58 & 8.97 & 0.28 & & & \\
\hline$X 107-1-17$ & 41.25 & 8428.09 & 9.36 & 0.58 & & & \\
\hline$X 107-1-18$ & 43.75 & 9129.61 & 11.69 & 0.65 & 0.2353 & & \\
\hline$x 107-1-19$ & 46.25 & 9831.12 & 12.61 & 1.05 & & & \\
\hline x107-1-20 & 48.75 & 10532.64 & 10.65 & 0.35 & 0.2751 & & \\
\hline x107-1-21 & 51.25 & 11218.82 & 9.95 & & & & \\
\hline$x 107-1-22$ & 53.25 & 11657.41 & 5.63 & 1.20 & 0.2888 & & \\
\hline x107-1-23 & 56.25 & 12315.30 & 5.00 & 3.43 & & & \\
\hline$x 107-1-24$ & 58.75 & 12863.54 & 6.14 & 2.64 & 0.3496 & & \\
\hline x107-1-25 & 61.25 & 13411.78 & 5.06 & & & & \\
\hline$x 107-1-26$ & 63.75 & 13960.02 & 5.00 & 4.25 & 0.3087 & & \\
\hline$x 107-1-27$ & 66.25 & 14508.25 & 4.50 & 7.16 & & & \\
\hline$x 107-1-28$ & 68.75 & 15056.49 & 4.31 & 6.32 & & 1.993 & -4.956 \\
\hline x107-1-29 & 71.50 & 15659.55 & 2.30 & & 0.3274 & 2.773 & -5.143 \\
\hline x107-2-01 & 74.25 & 16262.62 & 2.97 & 15.11 & 0.3798 & 2.182 & -6.283 \\
\hline x107-2-02 & 76.75 & 16810.85 & 1.86 & 19.39 & & 3.173 & -6.320 \\
\hline x107-2-03 & 79.25 & 17359.09 & 2.86 & 19.51 & 0.4100 & 1.919 & -6.684 \\
\hline$x 107-2-04$ & 81.75 & 17907.33 & 3.19 & 20.19 & & 1.466 & -6.499 \\
\hline$x 107-2-05$ & 84.25 & 18455.57 & 3.19 & 19.48 & 0.4168 & 1.239 & -6.699 \\
\hline$x 107-2-06$ & 86.75 & 19003.81 & 3.59 & 21.12 & & 1.198 & -6.491 \\
\hline$x 107-2-07$ & 89.25 & 19552.05 & 3.45 & 20.55 & 0.4043 & 0.846 & -6.647 \\
\hline x107-2-08 & 91.75 & 20100.28 & 3.59 & 15.17 & & 1.025 & -6.726 \\
\hline x107-2-09 & 94.25 & 20648.52 & 3.33 & 20.94 & 0.3904 & 1.186 & -6.446 \\
\hline x107-2-10 & 96.75 & 21196.76 & 3.79 & 21.73 & & 1.365 & -6.554 \\
\hline$x 107-2-11$ & 99.25 & 21745.00 & 3.42 & & 0.4245 & 0.459 & -6.629 \\
\hline$x 107-2-12$ & 101.75 & 21821.04 & 3.54 & 21.54 & & 0.697 & -6.686 \\
\hline$x 107-2-13$ & 104.25 & 21897.08 & 3.16 & 17.08 & 0.4260 & 1.757 & -6.130 \\
\hline$x 107-2-14$ & 106.75 & 21973.12 & 3.02 & 17.02 & & 1.611 & -6.148 \\
\hline x107-2-15 & 109.25 & 22049.16 & 3.29 & 21.01 & & 0.935 & -6.452 \\
\hline$x 107-2-16$ & 111.75 & 22125.20 & 2.93 & 22.21 & 0.3717 & 0.906 & -6.371 \\
\hline$x 107-2-17$ & 114.25 & 22201.24 & 2.86 & 20.79 & 0.3809 & 0.603 & -6.561 \\
\hline$x 107-2-18$ & 116.75 & 22277.28 & 2.95 & 23.85 & & 0.776 & -6.372 \\
\hline x107-2-19 & 119.25 & 22825.52 & 2.89 & 23.29 & 0.3485 & 1.549 & -5.899 \\
\hline x107-2-20 & 121.75 & 23373.76 & 2.49 & 18.64 & & 1.064 & -6.246 \\
\hline$x 107-2-21$ & 124.25 & 23922.00 & 2.63 & & 0.4239 & 1.014 & -6.240 \\
\hline$x 107-2-22$ & 126.75 & 24470.24 & 3.11 & 23.61 & 0.4090 & 0.736 & -6.216 \\
\hline$x 107-2-23$ & 129.25 & 25018.48 & 2.84 & 22.70 & & 0.686 & -7.029 \\
\hline$x 107-2-24$ & 131.75 & 25566.72 & 3.05 & & & 1.018 & -6.457 \\
\hline \multirow[t]{2}{*}{$x 107-2-25$} & 131.75 & 25566.72 & 2.73 & & & 0.284 & -6.694 \\
\hline & & & \multicolumn{3}{|c|}{ Blank space: not determined } & Cythe & a lacustri \\
\hline
\end{tabular}

Last-glacial to postglacial climate formation

K. Minoura et al.

Title Page

\begin{tabular}{c|c}
\hline Abstract & Introduction \\
\hline Conclusions & References \\
\hline Tables & Figures \\
\hline I4 & $-\mathbf{I}$ \\
\hline 4 & - \\
\hline Back & Close \\
\hline Full Screen / Esc \\
\hline Printer-friendly Version
\end{tabular}


Table 2. Calibrated ages of AMS radiocarbon isotope dates reported by Watanabe et al. (2009). Conventional ${ }^{14} \mathrm{C}$ ages were converted to calendar years using the INTCAL04 dataset (Reimer et al., 2004) after correcting the AMS dates by 500 years. *: wood fragment.

\begin{tabular}{|c|c|c|c|c|c|c|c|}
\hline \multirow[t]{2}{*}{$\begin{array}{l}\text { Sample No. } \\
\text { (Watanabe et } \\
\text { al., 2009) }\end{array}$} & \multicolumn{3}{|c|}{$\begin{array}{l}\text { Core depth } \\
\qquad(\mathrm{cm})\end{array}$} & \multirow{2}{*}{$\begin{array}{c}\text { AMS } \\
{ }^{14} \mathrm{C}_{\text {age }}^{* *} \\
\text { Yrs BP, } \pm 1 \text { sigma }\end{array}$} & \multicolumn{3}{|c|}{$\begin{array}{c}\text { Calibrated age }{ }^{\star \star \star} \\
\text { (cal BP) } \\
\text { (500 yrs adjustment) } \\
\text { yrs cal BP } \\
\text { range at } 1 \text { sigma }\end{array}$} \\
\hline & top & bottom & center & & $\begin{array}{l}\text { upper } \\
\text { range }\end{array}$ & $\begin{array}{l}\text { lower } \\
\text { range }\end{array}$ & median \\
\hline X103-1-1 & 0.0 & 2.5 & 1.25 & $2482 \pm 28$ & 1893 & 1985 & 1939.0 \\
\hline$X 103-1-3^{*}$ & - & - & 3.00 & $7825 \pm 34$ & 8559 & 8634 & 8596.5 \\
\hline X103-1-6 & 12.5 & 15.0 & 13.75 & $11954 \pm 42$ & 13257 & 13345 & 13301.0 \\
\hline X103-1-11 & 25.0 & 27.5 & 26.25 & $14974 \pm 50$ & 17183 & 17623 & 17403.0 \\
\hline $\mathrm{X} 103-1-21$ & 50.0 & 52.5 & 51.25 & $18618 \pm 58$ & 21305 & 21752 & 21528.5 \\
\hline X103-2-2 & 75.5 & 78.0 & 76.75 & $19122 \pm 59$ & 22141 & 22283 & 22212.0 \\
\hline X103-2-12 & 100.5 & 103.0 & 101.75 & $21883 \pm 70$ & - & - & - \\
\hline X103-2-18 & 115.5 & 118.0 & 116.75 & $23919 \pm 82$ & - & - & - \\
\hline X106-1-1 & 0.0 & 1.5 & 0.75 & $710 \pm 32$ & $<0$ & 299 & \\
\hline X106-1-5 & 6.0 & 7.5 & 6.75 & $1791 \pm 30$ & 1182 & 1278 & 1230.0 \\
\hline X106-1-15 & 21.0 & 22.5 & 21.75 & $4865 \pm 36$ & 4869 & 4962 & 4915.5 \\
\hline $\mathrm{X} 106-1-25$ & 36.0 & 37.5 & 36.75 & $8662 \pm 37$ & 9023 & 9130 & 9076.5 \\
\hline X106-1-35 & 51.0 & 52.5 & 51.75 & $12192 \pm 43$ & 13463 & 13612 & 13537.5 \\
\hline$\times 106-1-45$ & 66.0 & 67.5 & 66.75 & $15503 \pm 49$ & 18126 & 18530 & 18328.0 \\
\hline X106-1-49 & 72.0 & 73.0 & 72.50 & $17134 \pm 61$ & 19589 & 19879 & 19734.0 \\
\hline$\times 106-2-6$ & 80.5 & 82.0 & 81.25 & $18718 \pm 60$ & 21522 & 21917 & 21719.5 \\
\hline$X 106-2-16$ & 95.5 & 97.0 & 96.25 & $19312 \pm 66$ & 22278 & 22424 & 22351.0 \\
\hline$X 106-2-26$ & 110.5 & 112.0 & 111.25 & $21871 \pm 213$ & 25604 & 25985 & 25794.5 \\
\hline$X 106-2-37$ & 127.0 & 128.5 & 127.75 & $23989 \pm 87$ & - & - & - \\
\hline $\mathrm{X} 107-1-11$ & 25.0 & 27.5 & 26.25 & $4327 \pm 32$ & 4153 & 4285 & 4219.0 \\
\hline$X 107-1-21$ & 50.0 & 52.0 & 51.00 & $10207 \pm 38$ & 11127 & 11201 & 11164.0 \\
\hline$X 107-2-11$ & 98.0 & 100.5 & 99.25 & $18736 \pm 57$ & 21552 & 21938 & 21745.0 \\
\hline$\times 107-2-21$ & 123.0 & 125.5 & 124.25 & $20467 \pm 66$ & 23799 & 24045 & 23922.0 \\
\hline$X 107-2-24$ & 130.5 & 133.0 & 131.75 & $22661 \pm 81$ & - & - & - \\
\hline
\end{tabular}

$6,385-420,2010$

\section{Last-glacial to postglacial climate formation}

K. Minoura et al.
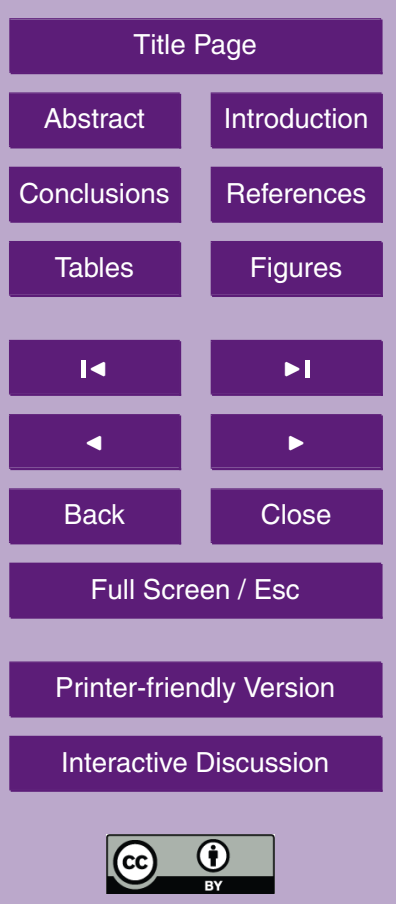

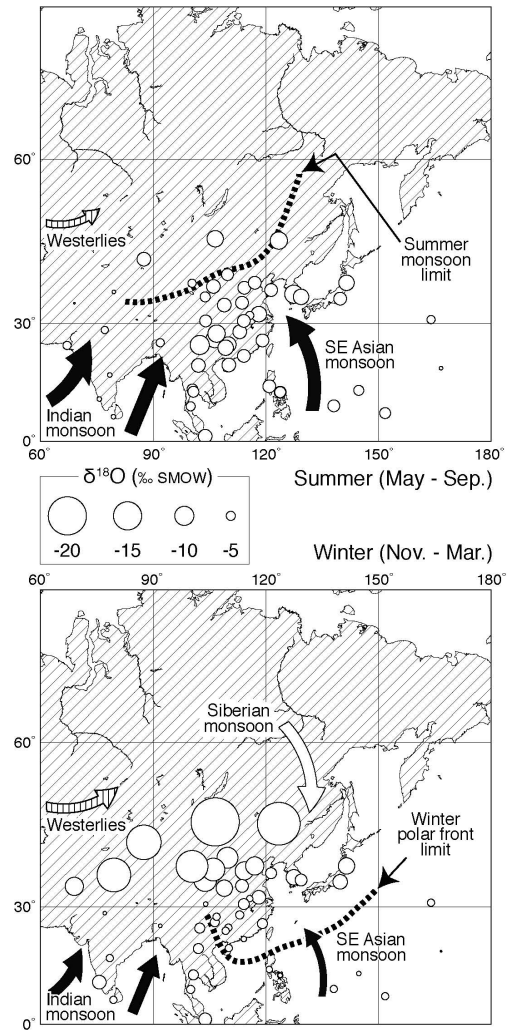

Fig. 1. Distribution of oxygen $\left(\delta^{18} \mathrm{O}\right)$ isotope ratios (\% SMOW, Standard Mean Ocean Water) of summer (May-September) and winter (November-March) precipitation, based on the averaged values of long term (1960-2001) International Atomic Energy Agency (IAEA) data (http://nucleus.iaea.org/NUCLEUS/nucleus/Content/index.jsp). The present-day average limits of the summer monsoons and the winter polar front, which are based on results reported by Gao (1962), Porter and An (1995), Dykoski et al. (2005), and Herzschuh (2006), are also shown.
6, 385-420, 2010

\section{Last-glacial to postglacial climate formation}

K. Minoura et al.

\section{Title Page}

Abstract

Introduction

Conclusions

References

Tables

Figures

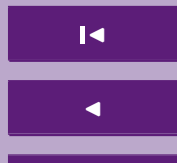

Back

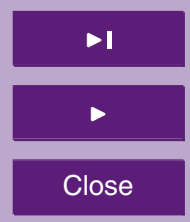

Full Screen / Esc

Printer-friendly Version

Interactive Discussion

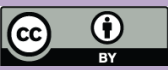




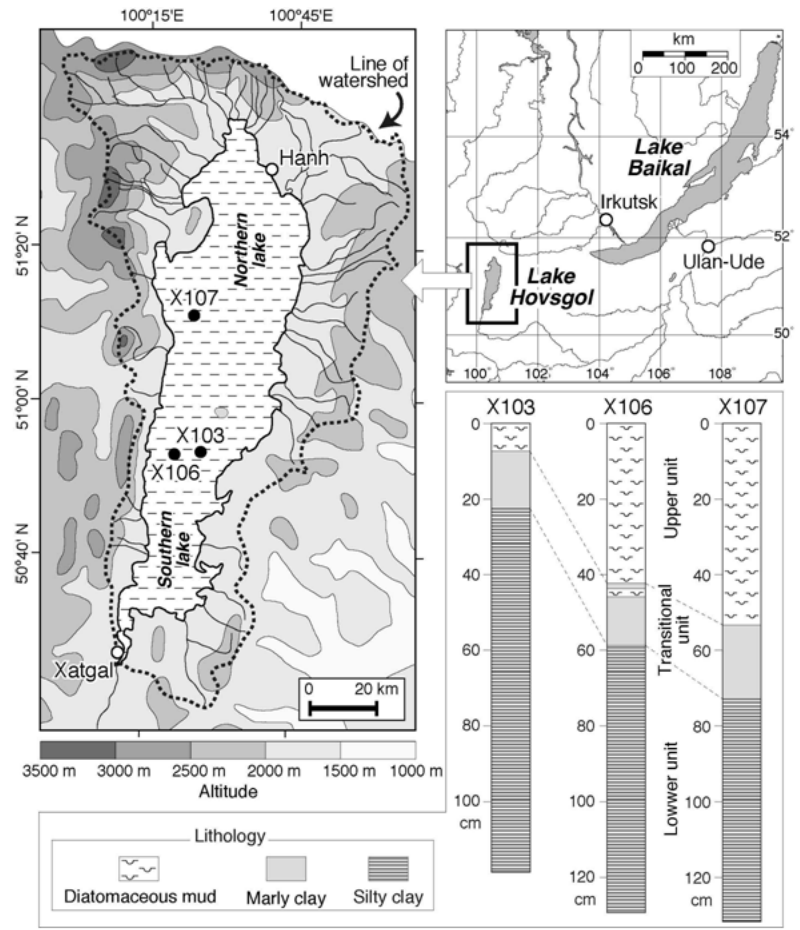

$6,385-420,2010$

\section{Last-glacial to postglacial climate formation}

K. Minoura et al.

Title Page

\begin{tabular}{|c|c|}
\hline Abstract & Introduction \\
\hline Conclusions & References \\
\hline Tables & Figures \\
\hline I4 & $\checkmark$ \\
\hline 4 & \\
\hline Back & Close \\
\hline Full Screen / Esc
\end{tabular}

Fig. 2. Location map of Lake Hovsgol. The coring sites are given in the map. Core lithology is shown in the lower right.

Printer-friendly Version

Interactive Discussion 


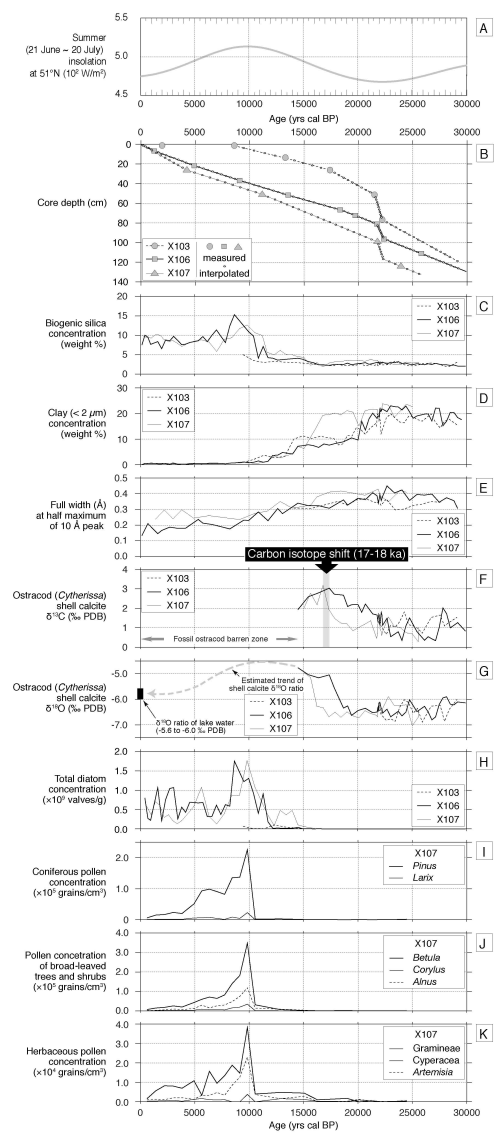

Fig. 3. Chronostratigraphic profiles on summer insolation changes (a) calculated using the data table provided by Laskar et al. (2004), age model (b), aquatic (biogenic silica) productivity (c), clay content (d), illite mineralogy (e), ostracod (Cytherissa lacustris) shell calcite $\delta^{13} \mathrm{C}(\mathrm{f})$ and $\delta^{18} \mathrm{O}(\mathrm{g})$ in PDB scale, total frustules (h), and pollen concentration (I, conifers; J, broad-leaved tress and shrubs; $\mathrm{K}$, herbs). Oxygen isotopes of lake water are shown in panel $\mathrm{G}\left(\delta^{18} \mathrm{O}\right.$ PDB). PDB denotes Peedee Belemnite Standard.
$6,385-420,2010$

\section{Last-glacial to postglacial climate formation}

K. Minoura et al.

\section{Title Page}

Abstract

Introduction

Conclusions

References

Tables

Figures

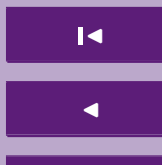

Back

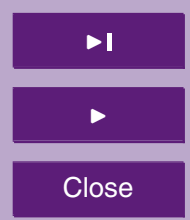

Full Screen / Esc

Printer-friendly Version

Interactive Discussion

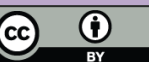

